\title{
Enantioselective Organo-SOMO Catalysis: The $\alpha$-Vinylation of Aldehydes
}

\author{
Hahn Kim and David W. C. MacMillan*
}

Merck Center for Catalysis at Princeton University, Princeton, New Jersey 08544

\section{Supporting Information}

General Information. Commercial reagents were purified prior to use following the guidelines of Perrin and Armarego. ${ }^{1}$ All solvents were purified according to the method of Grubbs. ${ }^{2}$ Organic solutions were concentrated under reduced pressure on a Büchi rotary evaporator using an ice-water bath for volatile compounds. Potassium trifluoroborate salts were synthesized from commercially or readily available boronic acids or esters using a modified Molander procedure. ${ }^{3}$ Chromatographic purification of products was accomplished using force-flow chromatography on Silicycle silica gel according to the method of Still ${ }^{4}$ and where noted, Iatrobeads 6RS-8060 was used in place of silica gel. Thin-layer chromatography (TLC) was performed on Silicycle 250 $\mu \mathrm{m}$ silica gel plates. Visualization of the developed chromatogram was performed by fluorescence quenching and anisaldehyde stain.

${ }^{1} \mathrm{H}$ and ${ }^{13} \mathrm{C}$ NMR spectra were recorded on a Varian Inova $400(400 \mathrm{MHz}$ or 100 $\mathrm{MHz}$ ) and are internally referenced to residual protio solvent signals (note: $\mathrm{CDCl}_{3}$

(1) Perrin, D. D.; Armarego, W. L. F. Purification of Laboratory Chemicals; $3^{\text {rd }}$ ed., Pergamon Press, Oxford, 1988.

(2) Pangborn, A. B.; Giardello, M. A.; Grubbs, R. H.; Rosen, R. K.; Timmers, F. J. Organometallics, 1996, $15,1518$.

(3) (a) Molander, G. A.; Ito, T. Org. Lett. 2001, 3, 393. (b) Molander, G. A.; Biolatto, B. Org. Lett. 2002, 4, 1867. Note: The cited procedures were found to be more efficient when reaction slurries were sonicated.

(4) Still, W. C.; Kahn, M.; Mitra, A. J. J. Org. Chem. 1978, 43, 2923. 
referenced at $\delta 7.27 \mathrm{ppm}$ for ${ }^{1} \mathrm{H}$ and $\delta 77.0 \mathrm{ppm}$ for ${ }^{13} \mathrm{C}$ ). Data for ${ }^{1} \mathrm{H}$ NMR are reported as follows: chemical shift $(\delta \mathrm{ppm})$, multiplicity $(\mathrm{s}=$ singlet, $\mathrm{d}=$ doublet, $\mathrm{t}=$ triplet, $\mathrm{q}=$ quartet, $\mathrm{m}=$ multiplet $)$, integration, coupling constant $(\mathrm{Hz})$ and assignment. Data for ${ }^{13} \mathrm{C}$ NMR are reported in terms of chemical shift. IR spectra were recorded on a Perkin Elmer Paragon 1000 spectrometer and are reported in terms of frequency of absorption $\left(\mathrm{cm}^{-1}\right)$. High Resolution Mass spectra were obtained from the Scripps Center for Mass Spectrometry. Supercritical fluid chromatography (SFC) was performed on a Berger Minigram equipped with a diode array UV detector $(\lambda=214-258 \mathrm{~nm})$ using a chiral column $(25 \mathrm{~cm})$ and guard column $(5 \mathrm{~cm})$ as noted for each compound. High Pressure Liquid chromatography (HPLC) was performed on a Hewlett-Packard 1100 Series chromatographs using a chiral column $(25 \mathrm{~cm})$ and guard column $(5 \mathrm{~cm})$ as noted for each compound.

General procedure using DME: To a 2 dram vial equipped with a Teflon septum and a magnetic stir bar was added the $\mathrm{BF}_{3} \mathrm{~K}$ salt (3.0 equiv.), (2S,5S)-5-benzyl-2tert-butyl-3-methylimidazolidin-4-one/ trifluoroacetic acid salt (0.2 eq), CAN (2.5 equiv.), and $\mathrm{NaHCO}_{3}$ (2.0 equiv.). The vial was then cooled to $-78{ }^{\circ} \mathrm{C}$ before DME (1.0 $\mathrm{mL}$ ) and $\mathrm{H}_{2} \mathrm{O}$ (4.0 equiv.) was added to the pre-cooled solid mixture. The reaction mixture was then carefully degassed through alternating vacuum evacuation and charging the vessel with argon (3X). Aldehyde $(0.25 \mathrm{mmol}, 1.0$ equiv.) was added after degassing of the reaction mixture and the reaction vial was moved and placed in $-50{ }^{\circ} \mathrm{C}$ cryocool reactor. After $24 \mathrm{~h}$, the reaction was quenched cold with Ether and stirred for 15 minutes where precipitation of white solid was observed. The reaction was then filtered through an iatrobeads plug and concentrated in vacuo $(\sim 1 \mathrm{~mL})$. The crude oil was directly diluted with DCM and EtOH (DCM : EtOH = $10 \mathrm{~mL}: 1 \mathrm{~mL})$ and $\mathrm{NaBH}_{4}$ (10 equiv.) was added. Upon complete consumption of the aldehyde, as indicated by TLC analysis, saturated $\mathrm{NH}_{4} \mathrm{Cl}(10 \mathrm{~mL})$ was added to the reaction mixture to quench the excess $\mathrm{NaBH}_{4}$. The mixture was then extracted with DCM (3 X $20 \mathrm{~mL}$ ). Combined organic layer were washed with $\mathrm{H}_{2} \mathrm{O}(20 \mathrm{~mL})$, brine $(20 \mathrm{~mL})$, dried over $\mathrm{MgSO}_{4}$ and concentrated in vacuo. 
The crude oil was purified by column chromatography with the solvent mixture as noted to yield the desired alcohol product.

General procedure using acetone: To a 2 dram vial equipped with a Teflon septum and a magnetic stir bar was added the $\mathrm{BF}_{3} \mathrm{~K}$ salt (5.0 equiv.), (2S,5S)-5-benzyl-2tert-butyl-3-methylimidazolidin-4-one / trifluoroacetic acid salt (0.2 eq), CAN (2.5 equiv. ), and $\mathrm{NaHCO}_{3}\left(2.0\right.$ equiv.). The vial was then cooled to $-78{ }^{\circ} \mathrm{C}$ before acetone $(2.0$ $\mathrm{mL}$ ) and $\mathrm{H}_{2} \mathrm{O}$ (4.0 equiv.) was added to the pre-cooled solid mixture. The reaction mixture was then carefully degassed through alternating vacuum evacuation and charging the vessel with argon $(3 \mathrm{X})$. Aldehyde $(0.125 \mathrm{mmol}, 1.0$ equiv.) was added after degassing of the reaction mixture and the reaction vial was moved and placed in $-50{ }^{\circ} \mathrm{C}$ cryocool reactor. After $24 \mathrm{~h}$, the reaction was quenched cold with Ether and stirred for 15 minutes where precipitation of white solid was observed. The reaction was then filtered through an iatrobeads plug and concentrated in vacuo $(\sim 1 \mathrm{~mL})$. The crude oil was directly diluted with DCM and EtOH (DCM : EtOH $=10 \mathrm{~mL}: 1 \mathrm{~mL})$ and $\mathrm{NaBH}_{4}(10$ equiv.) was added. Upon complete consumption of the aldehyde, as indicated by TLC analysis, saturated $\mathrm{NH}_{4} \mathrm{Cl}(10 \mathrm{~mL})$ was added to the reaction mixture to quench the excess $\mathrm{NaBH}_{4}$. The mixture was then extracted with DCM (3 X $20 \mathrm{~mL}$ ). Combined organic layer were washed with $\mathrm{H}_{2} \mathrm{O}(20 \mathrm{~mL})$, brine $(20 \mathrm{~mL})$, dried over $\mathrm{MgSO}_{4}$ and concentrated in vacuo. The crude oil was then purified by column chromatography with the solvent mixture as noted to yield the desired alcohol product.

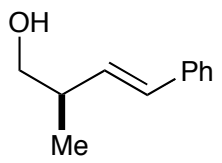

$(R, E)$-2-methyl-4-phenylbut-3-enol (Table 1, Entry 1) Prepared according to the general procedure using DME with propionaldehyde and potassium transstyryltrifluoroborate. To a 2 dram vial equipped with a Teflon septum and a magnetic stir bar was added the $\mathrm{BF}_{3} \mathrm{~K}$ salt (158 mg, $0.75 \mathrm{mmol}, 3.0$ equiv.), (2S,5S)-5-benzyl-2-tert- 
butyl-3-methylimidazolidin-4-one/ trifluoroacetic acid salt (18 mg, $0.05 \mathrm{mmol}, 0.20 \mathrm{eq})$, CAN (342 mg, $0.625 \mathrm{mmol}, 2.5$ equiv.), and $\mathrm{NaHCO}_{3}$ (42 mg, $0.5 \mathrm{mmol}, 2.0$ equiv.). The vial was then cooled to $-78{ }^{\circ} \mathrm{C}$ before DME $(1.0 \mathrm{~mL})$ and $\mathrm{H}_{2} \mathrm{O}(1.8 \mathrm{mg}, 1.0 \mathrm{mmol}, 4$ equiv.) was added to the pre-cooled solid mixture. The reaction mixture was then carefully degassed through alternating vacuum evacuation and charging the vessel with argon (3X). Aldehyde (14.5 mg, $0.25 \mathrm{mmol}, 1.0$ eqiuv.) was added after degassing of the reaction mixture and the reaction vial was moved and placed in $-50{ }^{\circ} \mathrm{C}$ cryocool. After 24 $\mathrm{h}$, the reaction was quenched cold with diethyl ether and stirred for 15 minutes during which precipitation of creamy white solid was observed. The reaction was then filtered through a plug of iatrobeads and concentrated in vacuo $(\sim 1 \mathrm{~mL})$. The crude oil was directly diluted with $\mathrm{DCM}$ and $\mathrm{EtOH}(\mathrm{DCM}: \mathrm{EtOH}=10 \mathrm{~mL}: 1 \mathrm{~mL})$ and $\mathrm{NaBH}_{4}(10$ equiv.) was added. Upon complete consumption of the desired aldehyde, as indicated by TLC analysis, saturated $\mathrm{NH}_{4} \mathrm{Cl}(10 \mathrm{~mL})$ was added to the reaction mixture to quench the excess $\mathrm{NaBH}_{4}$. The mixture was then extracted with DCM (3 X $\left.20 \mathrm{~mL}\right)$. Combined organic layers were washed with $\mathrm{H}_{2} \mathrm{O}(20 \mathrm{~mL})$, brine $(20 \mathrm{~mL})$, dried over $\mathrm{MgSO}_{4}$ and concentrated in vacuo. Purification by flash silica gel column chromatography (silica gel, $25 \%$ ether in pentane) gave the title compound as clear oil (29.2 mg, $72 \%$ yield, $94 \%$ ee). IR (film) 3346, 3026, 2925, 1599, 1031, 966, 740, $693 \mathrm{~cm}^{-1} ;{ }^{1} \mathrm{H}$ NMR (400 MHz, $\mathrm{CDCl}_{3}$ ) $\delta$ 7.40-7.38 (m, 2H, m-aryl H), 7.32 (t, $J=7.2 \mathrm{~Hz}, 2 \mathrm{H}, o$-aryl H), 7.25-7.21 (m, 1H, $p$ $\operatorname{aryl} \mathbf{H}), 6.50(\mathrm{~d}, J=15.9 \mathrm{~Hz}, 1 \mathrm{H}, \mathrm{CH}=\mathrm{CH}-\mathrm{Ph}), 6.10(\mathrm{dd}, J=15.9,8.0 \mathrm{~Hz}, 1 \mathrm{H}, \mathrm{Ph}-$ $\mathrm{CH}=\mathrm{CH}), 3.64-3.58\left(\mathrm{~m}, 1 \mathrm{H}, \mathrm{HOCH}_{\mathrm{a}} \mathrm{H}_{\mathrm{b}}-\mathrm{CH}\right), 3.53\left(\mathrm{dt}, J=7.6,3.2 \mathrm{~Hz}, 1 \mathrm{H}, \mathrm{HOCH}_{\mathrm{a}} \mathbf{H}_{\mathbf{b}}-\right.$ $\mathrm{CH}), 2.56\left(\mathrm{~m}, 1 \mathrm{H}, \mathrm{CHCH}_{3}\right), 1.53\left(\mathrm{t}, J=5.2 \mathrm{~Hz}, 1 \mathrm{H}, \mathbf{H O C H}_{\mathrm{a}} \mathrm{H}_{\mathrm{b}}\right), 1.16(\mathrm{~d}, J=6.7 \mathrm{~Hz}, 3 \mathrm{H}$, $\left.\mathrm{CH}_{3}\right) ;{ }^{13} \mathrm{C}$ NMR $\left(100 \mathrm{MHz}, \mathrm{CDCl}_{3}\right) \delta 137.1,132.4,131.0,128.5,127.3,126.1,67.3,40.2$, 16.5; HRMS (ESI-TOF) exact mass calculated for $[\mathrm{MH}]^{+\bullet}\left(\mathrm{C}_{11} \mathrm{H}_{15} \mathrm{O}\right)$ requires $\mathrm{m} / \mathrm{z}$ 163.1117, found $\mathrm{m} / \mathrm{z} 163.1111 ;[\alpha]_{\mathrm{D}}=42.8\left(\mathrm{c}=0.46, \mathrm{CHCl}_{3}\right)$. The enantiomeric excess was determined on by SFC analysis using a Chiralcel AS-H column $(5 \%$ to $50 \% \mathrm{MeOH}$, linear gradient, $100 \mathrm{bar}, 35^{\circ} \mathrm{C}$ oven, flow $\left.=4.0 \mathrm{~mL} / \mathrm{min}\right) ;(R)$ isomer $\mathrm{t}_{\mathrm{r}}=2.53 \mathrm{~min},(S)$ isomer $\mathrm{t}_{\mathrm{r}}=2.70 \mathrm{~min}$. 
Determination of the absolute stereochemistry: The sign of the optical rotation for the above compound is same as the identical compound reported in the literature; $[\alpha]_{D}=46.8$ ( $\mathrm{c}=0.75, \mathrm{CHCl}_{3}$ ), thus assigning the absolute configuration of the obtained product as the $(R)$ isomer. ${ }^{5}$

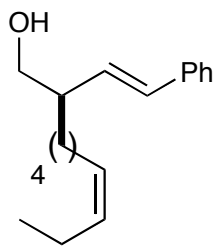

$(R, 4 Z)-2-(E)$-styrylhept-4-enol (Table 1, entry 2). Prepared according to the general procedure using DME with cis-7-decenal and potassium transstyryltrifluoroborate. To a 2 dram vial equipped with a Teflon septum and a magnetic stir bar was added the $\mathrm{BF}_{3} \mathrm{~K}$ salt (158 mg, $0.75 \mathrm{mmol}, 3.0$ equiv.), (2S,5S)-5-benzyl-2-tertbutyl-3-methylimidazolidin-4-one/ trifluoroacetic acid salt (18 mg, $0.05 \mathrm{mmol}, 0.20 \mathrm{eq}$ ), CAN (342 mg, $0.625 \mathrm{mmol}, 2.5$ equiv.), and $\mathrm{NaHCO}_{3}$ (42 mg, $0.5 \mathrm{mmol}, 2.0$ equiv.). The vial was then cooled to $-78{ }^{\circ} \mathrm{C}$ before $\mathrm{DME}(1.0 \mathrm{~mL})$ and $\mathrm{H}_{2} \mathrm{O}(1.8 \mathrm{mg}, 1.0 \mathrm{mmol}, 4$ equiv.) was added to the pre-cooled solid mixture. The reaction mixture was then carefully degassed through alternating vacuum evacuation and charging the vessel with argon (3X). Aldehyde (38.6 mg, $0.25 \mathrm{mmol}, 1.0$ equiv.) was added after degassing of the reaction mixture and the reaction vial was moved and placed in $-50{ }^{\circ} \mathrm{C}$ cryocool. After 24 $\mathrm{h}$, the reaction was quenched cold with diethyl ether and stirred for 15 minutes during which precipitation of creamy white solid was observed. The reaction was then filtered through an iatrobeads plug and concentrated in vacuo $(\sim 1 \mathrm{~mL})$. The crude oil was directly diluted with DCM and EtOH (DCM : EtOH $=10 \mathrm{~mL}: 1 \mathrm{~mL})$ and $\mathrm{NaBH}_{4}(10$ equiv.) was added. Upon complete consumption of the desired aldehyde, as indicated by TLC analysis, saturated $\mathrm{NH}_{4} \mathrm{Cl}(10 \mathrm{~mL})$ was added to the reaction mixture to quench the excess $\mathrm{NaBH}_{4}$. The mixture was then extracted with DCM (3 X $\left.20 \mathrm{~mL}\right)$. Combined

\footnotetext{
${ }^{5}$ Ohfune, Y.; Tomita, M. J. Am. Chem. Soc. 1992, 104, 3511
} 
organic layers were washed with $\mathrm{H}_{2} \mathrm{O}(20 \mathrm{~mL})$, brine $(20 \mathrm{~mL})$, dried over $\mathrm{MgSO}_{4}$ and concentrated in vacuo. Purification by flash silica gel column chromatography (silica gel, $25 \%$ ether in pentane) gave the title compound as clear oil (50.4 mg, $78 \%$ yield, 95\% ee). IR (film) 3361, 3003, 2925, 1598, 1449, 1041, 966, 748, $693 \mathrm{~cm}^{-1}$; ${ }^{1} \mathrm{H}$ NMR (400 MHz, $\left.\mathrm{CDCl}_{3}\right) \delta$ 7.40-7.38 (m, 2H, $m$-aryl H), $7.32(\mathrm{t}, J=2.0 \mathrm{~Hz}, 2 \mathrm{H}, o$-aryl $\mathbf{H}), 7.24(\mathrm{t}, J=2.0$ $\mathrm{Hz}, 1 \mathrm{H}, p$-aryl $\mathbf{H}), 6.50(\mathrm{~d}, J=15.9 \mathrm{~Hz}, 1 \mathrm{H}, \mathrm{CH}=\mathrm{CH}-\mathrm{Ph}), 5.99(\mathrm{dd}, J=15.9,8.8 \mathrm{~Hz}, 1 \mathrm{H}$, $\mathrm{Ph}-\mathrm{CH}=\mathrm{CH}), 5.40-5.28(\mathrm{~m}, 2 \mathrm{H}, \mathrm{CH}=\mathrm{CH}), 3.66(\mathrm{ddd}, J=13.1,8.0,5.2 \mathrm{~Hz}, 1 \mathrm{H}$, $\left.\mathrm{HOCH}_{\mathrm{a}} \mathrm{H}_{\mathrm{b}}-\mathrm{CH}\right), 3.51\left(\mathrm{~m} \mathrm{1H}, \mathrm{HOCH}_{\mathrm{a}} \mathbf{H}_{\mathbf{b}}-\mathrm{CH}\right), 2.40\left(\mathrm{~m}, 1 \mathrm{H}, \mathbf{C H C H}_{2}\right), 2.03(\mathrm{~m}, 4 \mathrm{H}$, $\mathrm{CH}=\mathrm{CH}-\mathrm{CH}), \quad 1.54-1.45\left(\mathrm{~m}, 2 \mathrm{H}, \mathrm{HOCH}_{\mathrm{a}} \mathrm{H}_{\mathrm{b}}-\mathrm{CH}-\mathrm{CH}_{2}-\right), 1.43-1.27\left(\mathrm{~m}, 5 \mathrm{H},-\mathrm{CH}_{2}-\right.$, $\left.\mathbf{H O C H}_{\mathrm{a}} \mathrm{H}_{\mathrm{b}}\right), 0.95\left(\mathrm{~d}, J=7.5 \mathrm{~Hz}, 3 \mathrm{H}, \mathrm{CH}_{3}\right) ;{ }^{13} \mathrm{C} \mathrm{NMR}\left(100 \mathrm{MHz}, \mathrm{CDCl}_{3}\right) \delta 137.0,132.5$, 131.7 131.5, 129.0, 128.5, 127.3, 126.1, 66.1, 46.4, 31.0, 29.8, 27.0, 6.8, 20.5, 14.4; HRMS (ESI-TOF) exact mass calculated for $[\mathrm{MH}]^{+\bullet}\left(\mathrm{C}_{18} \mathrm{H}_{27} \mathrm{O}\right)$ requires $\mathrm{m} / \mathrm{z}, 259.2056$, found $\mathrm{m} / \mathrm{z}$ 259.2063; $[\alpha]_{\mathrm{D}}=33.8\left(\mathrm{c}=0.8, \mathrm{CH}_{2} \mathrm{Cl}_{2}\right)$. The enantiomeric excess was determined by SFC analysis using a Chiralcel OJ-H column (5\% to $10 \% \mathrm{MeOH}$, linear gradient, 100 bar, $35^{\circ} \mathrm{C}$ oven, flow $\left.=4.0 \mathrm{~mL} / \mathrm{min}\right) ;(R)$ isomer $\mathrm{t}_{\mathrm{r}}=4.47 \mathrm{~min},(S)$ isomer $\mathrm{t}_{\mathrm{r}}$ $=5.02 \mathrm{~min}$.

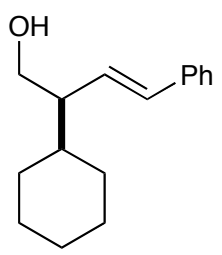

$(R, E)$-2-cyclohexyl-4-phenylbut-3-enol (Table 1, entry 3) Prepared according to the general procedure using DME with 2-cyclohexane-1-al and potassium transstyryltrifluoroborate. To a 2 dram vial equipped with a Teflon septum and a magnetic stir bar was added the $\mathrm{BF}_{3} \mathrm{~K}$ salt (158 mg, $0.75 \mathrm{mmol}, 3.0$ equiv.), (2S,5S)-5-benzyl-2-tertbutyl-3-methylimidazolidin-4-one/ trifluoroacetic acid salt (18 mg, $0.05 \mathrm{mmol}, 0.20 \mathrm{eq}$ ), CAN (342 mg, $0.625 \mathrm{mmol}, 2.5$ equiv.), and $\mathrm{NaHCO}_{3}$ (42 mg, $0.5 \mathrm{mmol}, 2.0$ equiv.). The vial was then cooled to $-78{ }^{\circ} \mathrm{C}$ before DME $(1.0 \mathrm{~mL})$ and $\mathrm{H}_{2} \mathrm{O}(1.8 \mathrm{mg}, 1.0 \mathrm{mmol}, 4$ equiv.) was added to the pre-cooled solid mixture. The reaction mixture was then 
carefully degassed through alternating vacuum evacuation and charging the vessel with argon (3X). Aldehyde (31.5 mg, $0.25 \mathrm{mmol}, 1.0$ equiv.) was added after degassing of the reaction mixture and the reaction vial was moved and placed in $-50{ }^{\circ} \mathrm{C}$ cryocool. After 24 $\mathrm{h}$, the reaction was quenched cold with diethyl ether and stirred for 15 minutes during which precipitation of creamy white solid was observed. The reaction was then filtered through an iatrobeads plug and concentrated in vacuo $(\sim 1 \mathrm{~mL})$. The crude oil was directly diluted with DCM and EtOH (DCM : EtOH $=10 \mathrm{~mL}: 1 \mathrm{~mL})$ and $\mathrm{NaBH}_{4}(10$ equiv.) was added. Upon complete consumption of the desired aldehyde, as indicated by TLC analysis, saturated $\mathrm{NH}_{4} \mathrm{Cl}(10 \mathrm{~mL})$ was added to the reaction mixture to quench the excess $\mathrm{NaBH}_{4}$. The mixture was then extracted with DCM (3 X $\left.20 \mathrm{~mL}\right)$. Combined organic layers were washed with $\mathrm{H}_{2} \mathrm{O}(20 \mathrm{~mL})$, brine $(20 \mathrm{~mL})$, dried over $\mathrm{MgSO}_{4}$ and concentrated in vacuo. Purification by flash silica gel column chromatography (silica gel, $25 \%$ ether in pentane) gave the title compound as clear oil (47.2 $\mathrm{mg}, 82 \%$ yield, $96 \%$ ee). IR (film) 3290, 2920, 2849, 1598, 1447, 1010, 968, 748, $693 \mathrm{~cm}^{-1}$; ${ }^{1} \mathrm{H}$ NMR (400 MHz, $\left.\mathrm{CDCl}_{3}\right) \delta$ 7.41-7.38 (m, 2H, $m$-aryl H), 7.35-7.30 (m, 2H, $o$-aryl H), 7.26-7.22 (m, $1 \mathrm{H}, p$ $\operatorname{aryl} \mathbf{H}), 6.48(\mathrm{~d}, J=15.9 \mathrm{~Hz}, 1 \mathrm{H}, \mathrm{CH}=\mathrm{CH}-\mathrm{Ph}), 6.06(\mathrm{dd}, J=15.9,9.0 \mathrm{~Hz}, 1 \mathrm{H}, \mathrm{Ph}-$ $\mathrm{CH}=\mathrm{CH}), 3.78\left(\mathrm{ddd}, J=13.5,8.5,4.8 \mathrm{~Hz}, 1 \mathrm{H}, \mathrm{HOC} \mathbf{H}_{\mathrm{a}} \mathrm{H}_{\mathrm{b}}-\mathrm{CH}\right), 3.56$ (ddd, $J=12.0,8.8$, $\left.3.2 \mathrm{~Hz}, 1 \mathrm{H}, \mathrm{HOCH}_{\mathrm{a}} \mathbf{H}_{\mathrm{b}}-\mathrm{CH}\right), 2.22\left(\mathrm{~m}, 1 \mathrm{H}, \mathrm{HOCH}_{\mathrm{a}} \mathrm{H}_{\mathrm{b}}-\mathrm{CH}\right), 1.75-1.65(\mathrm{~m}, 5 \mathrm{H},-\mathbf{C H}-$, $\left.\mathrm{CH}_{2}-\right), 1.50-1.41\left(\mathrm{~m}, 2 \mathrm{H},-\mathrm{CH}_{2}-\right), 1.29-1.00\left(\mathrm{~m}, 5 \mathrm{H},-\mathrm{CH}_{2^{-}}, \mathbf{H O C H}_{\mathrm{a}} \mathrm{H}_{\mathrm{b}}\right) ;{ }^{13} \mathrm{C}$ NMR (100 $\left.\mathrm{MHz}, \mathrm{CDCl}_{3}\right) \delta 137.0,133.2,130.2,128.5,127.3,126.1,63.9,52.3,39.0,31.2,30.4$, 26.5; HRMS (ESI-TOF) exact mass calculated for $[\mathrm{MH}]^{+*}\left(\mathrm{C}_{16} \mathrm{H}_{23} \mathrm{O}\right)$ requires $\mathrm{m} / \mathrm{z}$ 231.1743, found $m / z$ 231.1748; $[\alpha]_{D}=-48.6\left(\mathrm{c}=1.15, \mathrm{CH}_{2} \mathrm{Cl}_{2}\right)$. The enantiomeric excess was determined by SFC analysis using a Chiralcel OJ-H column (5\% to $10 \% \mathrm{MeOH}$, linear gradient, $100 \mathrm{bar}, 35^{\circ} \mathrm{C}$ oven, flow $\left.=4.0 \mathrm{~mL} / \mathrm{min}\right) ;(R)$ isomer $\mathrm{t}_{\mathrm{r}}=4.32 \mathrm{~min},(S)$ isomer $\mathrm{t}_{\mathrm{r}}=4.95 \mathrm{~min}$. 


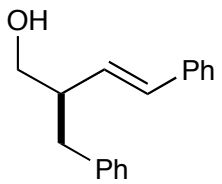

(R,E)-2-benzyl-4-phenylbut-3-enol (Table 1, entry 4) Prepared according to the general procedure using DME with 3-phenyl-propionaldehyde and potassium transstyryltrifluoroborate. To a 2 dram vial equipped with a Teflon septum and a magnetic stir bar was added the $\mathrm{BF}_{3} \mathrm{~K}$ salt (158 $\mathrm{mg}, 0.75 \mathrm{mmol}, 3.0$ equiv.), (2S,5S)-5-benzyl-2-tertbutyl-3-methylimidazolidin-4-one/ trifluoroacetic acid salt (18 mg, $0.05 \mathrm{mmol}, 0.20 \mathrm{eq})$, CAN (342 mg, 0.625 mmol, 2.5 equiv.), and $\mathrm{NaHCO}_{3}$ (42 mg, $0.5 \mathrm{mmol}, 2.0$ equiv.). The vial was then cooled to $-78{ }^{\circ} \mathrm{C}$ before DME $(1.0 \mathrm{~mL})$ and $\mathrm{H}_{2} \mathrm{O}(1.8 \mathrm{mg}, 1.0 \mathrm{mmol}, 4$ equiv.) was added to the pre-cooled solid mixture. The reaction mixture was then carefully degassed through alternating vacuum evacuation and charging the vessel with argon (3X). Aldehyde (33.5 mg, $0.25 \mathrm{mmol}, 1.0$ equiv.) was added after degassing of the reaction mixture and the reaction vial was moved and placed in $-50{ }^{\circ} \mathrm{C}$ cryocool. After 24 $\mathrm{h}$, the reaction was quenched cold with diethyl ether and stirred for 15 minutes during which precipitation of creamy white solid was observed. The reaction was then filtered through an iatrobeads plug and concentrated in vacuo $(\sim 1 \mathrm{~mL})$. The crude oil was directly diluted with DCM and EtOH (DCM : EtOH $=10 \mathrm{~mL}: 1 \mathrm{~mL})$ and $\mathrm{NaBH}_{4}(10$ equiv.) was added. Upon complete consumption of the desired aldehyde, as indicated by TLC analysis, saturated $\mathrm{NH}_{4} \mathrm{Cl}(10 \mathrm{~mL})$ was added to the reaction mixture to quench the excess $\mathrm{NaBH}_{4}$. The mixture was then extracted with DCM (3 X $\left.20 \mathrm{~mL}\right)$. Combined organic layer were washed with $\mathrm{H}_{2} \mathrm{O}(20 \mathrm{~mL})$, brine $(20 \mathrm{~mL})$, dried over $\mathrm{MgSO}_{4}$ and concentrated in vacuo. Purification by flash silica gel column chromatography (silica gel, $25 \%$ ether in pentane) gave the title compound as clear oil ( $47.1 \mathrm{mg}, 79 \%$ yield, $93 \%$ ee). IR (film) 3356, 2923, 1601, 1494, 1030, 966, 747, $694 \mathrm{~cm}^{-1} ;{ }^{1} \mathrm{H}$ NMR (400 MHz, $\mathrm{CDCl}_{3}$ ) $\delta$ 7.35-7.14 (m, 9H, aryl H), 6.40 (d, $J=15.9 \mathrm{~Hz}, 1 \mathrm{H}, \mathrm{CH}=\mathrm{CH}-\mathrm{Ph}), \mathrm{Ph}-\mathrm{CH}=\mathrm{CH}), 3.65$ (ddd, $\left.J=10.8,7.2,4.8 \mathrm{~Hz}, 1 \mathrm{H}, \mathrm{HOCH}_{\mathrm{a}} \mathrm{H}_{\mathrm{b}}-\mathrm{CH}\right), 3.54(\mathrm{ddd}, J=11.1,7.2,4.4 \mathrm{~Hz}, 1 \mathrm{H}$, $\left.\mathrm{HOCH}_{\mathrm{a}} \mathbf{H}_{\mathrm{b}}-\mathrm{CH}\right), 2.80\left(\mathrm{dd}, \mathrm{J}=13.2,7.2 \mathrm{~Hz}, 1 \mathrm{H}, \mathrm{HOCH}_{\mathrm{a}} \mathrm{H}_{\mathbf{b}}-\mathrm{CH}\right), 2.77-2.71(\mathrm{~m}, 2 \mathrm{H}$, $\left.\mathrm{CH}_{2}-\mathrm{Ar}\right) ;{ }^{13} \mathrm{C}$ NMR $\left(100 \mathrm{MHz}, \mathrm{CDCl}_{3}\right) \delta$ 139.5, 137.0, 132.4, 130.6, 129.2, 128.5, 128.3, 
127.4, 126.14, 126.08, 65.1, 47.5, 37.8; HRMS (ESI-TOF) exact mass calculated for $[\mathrm{MNa}]^{+\bullet}\left(\mathrm{C}_{17} \mathrm{H}_{18} \mathrm{ONa}\right)$ requires $m / z$ 261.125, found $\mathrm{m} / z$ 261.1257; $[\alpha]_{\mathrm{D}}=-111.2(\mathrm{c}=0.45$, $\mathrm{CH}_{2} \mathrm{Cl}_{2}$ ). The enantiomeric excess was determined on by SFC analysis using a Chiralcel $\mathrm{AD}-\mathrm{H}$ column $\left(35 \% \mathrm{MeOH}\right.$, isocratic, $100 \mathrm{bar}, 35^{\circ} \mathrm{C}$ oven, flow $\left.=3.0 \mathrm{~mL} / \mathrm{min}\right) ;(R)$ isomer $\mathrm{t}_{\mathrm{r}}=3.67 \mathrm{~min},(S)$ isomer $\mathrm{t}_{\mathrm{r}}=4.67 \mathrm{~min}$.

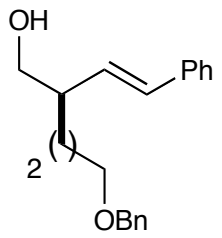

(R,E)-2-(2-(benzyloxy)ethyl)-4-phenylbut-3-enol (Table 1, entry 5) Prepared according to the general procedure using DME with 5-benzyloxy-pentenal and potassium trans-styryltrifluoroborate. To a 2 dram vial equipped with a Teflon septum and a magnetic stir bar was added the $\mathrm{BF}_{3} \mathrm{~K}$ salt (158 mg, $0.75 \mathrm{mmol}, 3.0$ equiv.), (2S,5S)-5benzyl-2-tert-butyl-3-methylimidazolidin-4-one/ trifluoroacetic acid (18 mg, $0.05 \mathrm{mmol}$, 0.20 eq), CAN (342 mg, $0.625 \mathrm{mmol}, 2.5$ equiv.), and $\mathrm{NaHCO}_{3}(42 \mathrm{mg}, 0.5 \mathrm{mmol}, 2.0$ equiv.). The vial was then cooled to $-78{ }^{\circ} \mathrm{C}$ before $\mathrm{DME}(1.0 \mathrm{~mL})$ and $\mathrm{H}_{2} \mathrm{O}(1.8 \mathrm{mg}, 1.0$ mmol, 4 equiv.) was added to the pre-cooled solid mixture. The reaction mixture was then carefully degassed through alternating vacuum evacuation and charging the vessel with argon (3X). Aldehyde (48.1 mg, $0.25 \mathrm{mmol}, 1.0$ equiv.) was added after degassing of the reaction mixture and the reaction vial was moved and placed in $-50{ }^{\circ} \mathrm{C}$ cryocool. After $24 \mathrm{~h}$, the reaction was quenched cold with diethyl ether and stirred for 15 minutes during which precipitation of creamy white solid was observed. The reaction was then filtered through an iatrobeads plug and concentrated in vacuo $(\sim 1 \mathrm{~mL})$. The crude oil was directly diluted with DCM and EtOH (DCM : EtOH $=10 \mathrm{~mL}: 1 \mathrm{~mL})$ and $\mathrm{NaBH}_{4}(10$ equiv.) was added. Upon complete consumption of the desired aldehyde, as indicated by TLC analysis, saturated $\mathrm{NH}_{4} \mathrm{Cl}(10 \mathrm{~mL})$ was added to the reaction mixture to quench the excess $\mathrm{NaBH}_{4}$. The mixture was then extracted with DCM (3 X $\left.20 \mathrm{~mL}\right)$. Combined 
organic layer was washed with $\mathrm{H} 2 \mathrm{O}(20 \mathrm{~mL})$, Brine $(20 \mathrm{~mL})$, dried under $\mathrm{MgSO}_{4}$ and concentrated in vacuo. Purification by flash silica gel column chromatography (silica gel, $25 \%$ ether in pentane) gave the title compound as clear oil (57.8 mg, $78 \%$ yield, 93\% ee). IR (film) 3399, 3026, 2938, 2860, 1598, 1453, 1097, 968, 746, $693 \mathrm{~cm}^{-1}$; ${ }^{1} \mathrm{H}$ NMR (400 MHz, $\left.\mathrm{CDCl}_{3}\right) \delta$ 7.39-7.22 (m, 9H, aryl H), $6.50(\mathrm{~d}, 1 \mathrm{H}, J=15.9 \mathrm{~Hz}, \mathrm{CH}=\mathrm{CH}-\mathrm{Ph}), 6.00$ (dd, 1H, $J=15.9,9.2 \mathrm{~Hz}, \mathrm{Ph}-\mathrm{CH}=\mathrm{CH}), 4.50\left(\mathrm{~s}, 2 \mathrm{H}, \mathrm{O}-\mathrm{CH}_{2}-\mathrm{Ar}\right) 3.66\left(\mathrm{~m}, 1 \mathrm{H}, \mathrm{HOCH}_{\mathbf{a}} \mathrm{H}_{\mathrm{b}}-\right.$ $\mathrm{CH})$, 3.56-3.47 (m, 1H, $\left.\mathrm{HOCH}_{\mathrm{a}} \mathbf{H}_{\mathrm{b}}-\mathrm{CH}\right), 3.50\left(\mathrm{t}, 2 \mathrm{H}, J=6.0 \mathrm{~Hz},-\mathrm{CH}_{2}-\mathrm{OBn}\right), 2.41(\mathrm{~m}$, $\left.1 \mathrm{H}, \mathrm{HOCH}_{\mathrm{a}} \mathrm{H}_{\mathrm{b}}-\mathbf{C H}\right), 1.80-1.57\left(\mathrm{~m}, 4 \mathrm{H},-\mathbf{C H}_{2}-\mathbf{H O C H}_{\mathrm{a}} \mathrm{H}_{\mathrm{b}}\right), 1.48-1.36\left(\mathrm{~m}, 1 \mathrm{H},-\mathrm{CH}_{\mathrm{a}} \mathbf{H}_{\mathrm{b}}-\right.$ ); ${ }^{13} \mathrm{C}$ NMR $\left(100 \mathrm{MHz}, \mathrm{CDCl}_{3}\right) \delta 138.4,137.0,132.6,131.1,128.5,128.3,127.6,127.5$, 127.3, 126.1, 72.9, 70.2, 66.0, 46.2, 27.7, 27.4; HRMS (ESI-TOF) exact mass calculated for $[\mathrm{MH}]^{+\bullet}\left(\mathrm{C}_{20} \mathrm{H}_{25} \mathrm{O}_{2}\right)$ requires $\mathrm{m} / \mathrm{z} 297.1849$, found $\mathrm{m} / \mathrm{z} 297.1854 ;[\alpha]_{\mathrm{D}}=-25.5(\mathrm{c}=1.85$, $\mathrm{CH}_{2} \mathrm{Cl}_{2}$ ). The enantiomeric excess was determined on by SFC analysis using a Chiralcel AS-H column $\left(5 \%\right.$ to $10 \% \mathrm{MeOH}$, linear gradient, 100 bar, $35{ }^{\circ} \mathrm{C}$ oven, flow $=4.0$ $\mathrm{mL} / \mathrm{min}) ;(R)$ isomer $\mathrm{t}_{\mathrm{r}}=5.06 \mathrm{~min},(S)$ isomer $\mathrm{t}_{\mathrm{r}}=5.62 \mathrm{~min}$.

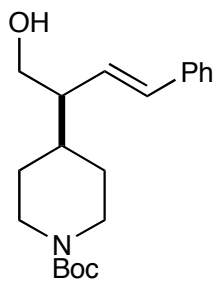

tert-butyl 4-((R,E)-1-hydroxy-4-phenylbut-3-en-2-yl)piperidine-1-carboxylate (Table 1, entry 6) Prepared according to the general procedure using DME with tertbutyl 4-(formyl methyl)piperidine-1-carboxylate and potassium transstyryltrifluoroborate. To a 2 dram vial equipped with a Teflon septum and a magnetic stir bar was added the $\mathrm{BF}_{3} \mathrm{~K}$ salt (158 mg, $0.75 \mathrm{mmol}, 3.0$ equiv.), (2S,5S)-5-benzyl-2-tertbutyl-3-methylimidazolidin-4-one/ trifluoroacetic acid salt (18 mg, $0.05 \mathrm{mmol}, 0.20 \mathrm{eq}$ ), CAN (301 mg, $0.5 \mathrm{mmol}, 2.2$ equiv.), and $\mathrm{NaHCO}_{3}(42 \mathrm{mg}, 0.5 \mathrm{mmol}, 2.0$ equiv.). The vial was then cooled to $-78{ }^{\circ} \mathrm{C}$ before DME $(1.0 \mathrm{~mL})$ and $\mathrm{H}_{2} \mathrm{O}(1.8 \mathrm{mg}, 1.0 \mathrm{mmol}, 4$ equiv.) was added to the pre-cooled solid mixture. The reaction mixture was then carefully degassed through alternating vacuum evacuation and charging the vessel with 
argon (3X). Aldehyde (56.8 mg, $0.25 \mathrm{mmol}, 1.0$ equiv.) was added after degassing of the reaction mixture and the reaction vial was moved and placed in $-50{ }^{\circ} \mathrm{C}$ cryocool. After 24 $\mathrm{h}$, the reaction was quenched cold with diethyl ether and stirred for 15 minutes during which precipitation of creamy white solid was observed. The reaction was then filtered through an iatrobeads plug and concentrated in vacuo $(\sim 1 \mathrm{~mL})$. The crude oil was directly diluted with DCM and EtOH (DCM : EtOH $=10 \mathrm{~mL}: 1 \mathrm{~mL})$ and $\mathrm{NaBH}_{4}(10$ equiv.) was added. Upon complete consumption of the desired aldehyde, as indicated by TLC analysis, saturated $\mathrm{NH}_{4} \mathrm{Cl}(10 \mathrm{~mL})$ was added to the reaction mixture to quench the excess $\mathrm{NaBH}_{4}$. The mixture was then extracted with DCM (3 X $20 \mathrm{~mL}$ ). Combined organic layer were washed with $\mathrm{H}_{2} \mathrm{O}(20 \mathrm{~mL})$, brine $(20 \mathrm{~mL})$, dried over $\mathrm{MgSO}_{4}$ and concentrated in vacuo. Purification by flash silica gel column chromatography (silica gel, $25 \%$ ether in pentane) gave the title compound as clear oil ( $67.9 \mathrm{mg}, 82 \%$ yield, $96 \%$ ee). IR (film) 3420, 2932, 2853, 1667, 1424, 1365, 1136, 1010, 968, 749, $694 \mathrm{~cm}^{-1} ;{ }^{1} \mathrm{H}$ NMR $\left(400 \mathrm{MHz}, \mathrm{CDCl}_{3}\right) \delta 7.38(\mathrm{~d}, 2 \mathrm{H}, J=7.6 \mathrm{~Hz}, m$-aryl H), $7.32(\mathrm{~d}, 2 \mathrm{H}, J=7.2 \mathrm{~Hz}, o$-aryl H), 7.26-7.22 (m, 1H, p-aryl H), $6.48(\mathrm{~d}, 1 \mathrm{H}, J=15.9 \mathrm{~Hz}, \mathrm{CH}=\mathrm{CH}), 6.03(\mathrm{dd}, 1 \mathrm{H}, J=$ 15.9, 9.6 Hz, CH=CH), 4.15-4.09 (m, 2H, $\left.\mathrm{CH}_{\mathrm{eq}} \mathrm{H}_{\mathrm{ax}}-\mathrm{N}-\mathrm{CH}_{\mathrm{eq}} \mathrm{H}_{\mathrm{ax}}\right) 3.78\left(\mathrm{~m}, 1 \mathrm{H}, \mathrm{HOCH}_{\mathrm{a}} \mathrm{H}_{\mathrm{b}}-\right.$ $\mathrm{CH}), 3.61\left(\mathrm{t}, J=9.8 \mathrm{~Hz}, \mathrm{HOCH}_{\mathrm{a}} \mathbf{H}_{\mathrm{b}}-\mathrm{CH}\right), 2.68\left(\mathrm{~m}, 2 \mathrm{H}, \mathrm{CH}_{\mathrm{eq}} \mathbf{H}_{\mathrm{ax}}-\mathrm{N}_{-} \mathrm{CH}_{\mathrm{eq}} \mathbf{H}_{\mathrm{ax}}\right), 2.24(\mathrm{q}, 1 \mathrm{H}$, $\left.J=7.2 \mathrm{~Hz}, \mathrm{HOCH}_{\mathrm{a}} \mathrm{H}_{\mathrm{b}}-\mathbf{C H}\right), 1.74-1.58\left(\mathrm{~m}, 4 \mathrm{H},-\mathbf{C H}-, \mathbf{C H}_{\mathrm{eq}} \mathrm{H}_{\mathrm{ax}}-\mathrm{CH}-\mathrm{CH}_{\mathrm{eq}} \mathrm{H}_{\mathrm{ax}}, \mathbf{H O C H}_{\mathrm{a}} \mathrm{H}_{\mathrm{b}}\right)$, $1.45\left(\mathrm{~s}, 9 \mathrm{H}, \mathrm{C}\left(\mathrm{CH}_{3}\right)_{3}\right), 1.32-1.14\left(\mathrm{~m}, 2 \mathrm{H}, \mathrm{CH}_{\mathrm{eq}} \mathbf{H}_{\mathrm{ax}} \mathrm{CH}-\mathrm{CH}_{\mathrm{eq}} \mathbf{H}_{\mathrm{ax}}\right) ;{ }^{13} \mathrm{C} \mathrm{NMR}(100 \mathrm{MHz}$, $\left.\mathrm{CDCl}_{3}\right) \delta 154.7,136.8,133.7,129.1,128.6,127.5,126.1,79.3,63.5,51.4,43.8,37.1$, 30.2, 28.4; HRMS (ESI-TOF) exact mass calculated for $[\mathrm{MH}]^{+\bullet}\left(\mathrm{C}_{20} \mathrm{H}_{30} \mathrm{NO}_{3}\right)$ requires $\mathrm{m} / \mathrm{z}$ 332.222, found $\mathrm{m} / \mathrm{z} 332.2216 ;[\alpha]_{\mathrm{D}}=-45.6\left(\mathrm{c}=3.1, \mathrm{CH}_{2} \mathrm{Cl}_{2}\right)$. The enantiomeric excess was determined on by SFC analysis using a Chiralcel AS-H column (5\% to $10 \% \mathrm{MeOH}$, linear gradient, $100 \mathrm{bar}, 35{ }^{\circ} \mathrm{C}$ oven, flow $\left.=4.0 \mathrm{~mL} / \mathrm{min}\right) ;(R)$ isomer $\mathrm{t}_{\mathrm{r}}=6.14 \min ,(S)$ isomer $\mathrm{t}_{\mathrm{r}}=4.96 \mathrm{~min}$. 


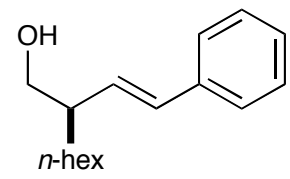

(R)-2-styryloctanol (Table 2, entry 1). Prepared according to the general procedure using DME with 1-octanal and potassium trans-styryltrifluoroborate. To a 2 dram vial equipped with a Teflon septum and a magnetic stir bar was added the $\mathrm{BF}_{3} \mathrm{~K}$ salt (158 mg, 0.75 mmol, 3.0 equiv.), (2S,5S)-5-benzyl-2-tert-butyl-3-methylimidazolidin-4one/ trifluoroacetic acid salt (18 mg, $0.05 \mathrm{mmol}, 0.20 \mathrm{eq})$, CAN (342 mg, $0.625 \mathrm{mmol}$, 2.5 equiv.), and $\mathrm{NaHCO}_{3}$ (42 mg, $0.5 \mathrm{mmol}, 2.0$ equiv.). The vial was then cooled to -78 ${ }^{\circ} \mathrm{C}$ before DME (1.0 mL) and $\mathrm{H}_{2} \mathrm{O}(1.8 \mathrm{mg}, 1.0 \mathrm{mmol}, 4$ equiv.) were added to the precooled solid mixture. The reaction mixture was then carefully degassed through alternating vacuum evacuation and charging the vessel with argon (3X). Aldehyde (32 $\mathrm{mg}, 0.25 \mathrm{mmol}, 1.0$ equiv.) was added after degassing of the reaction mixture and the reaction vial was moved and placed in $-50{ }^{\circ} \mathrm{C}$ cryocool. After $24 \mathrm{~h}$, the reaction was quenched cold with diethyl ether and stirred for 15 minutes during which precipitation of creamy white solid was observed. The reaction was then filtered through an iatrobeads plug and concentrated in vacuo $(\sim 1 \mathrm{~mL})$. The crude oil was directly diluted with DCM and $\mathrm{EtOH}(\mathrm{DCM}: \mathrm{EtOH}=10 \mathrm{~mL}: 1 \mathrm{~mL})$ and $\mathrm{NaBH}_{4}$ (10 equiv.) was added. Upon complete consumption of the desired aldehyde, as indicated by TLC analysis, saturated $\mathrm{NH}_{4} \mathrm{Cl}(10 \mathrm{~mL})$ was added to the reaction mixture to quench the excess $\mathrm{NaBH}_{4}$. The mixture was then extracted with DCM (3 X $20 \mathrm{~mL})$. Combined organic layers were washed with $\mathrm{H}_{2} \mathrm{O}(20 \mathrm{~mL})$, brine $(20 \mathrm{~mL})$, dried over $\mathrm{MgSO}_{4}$ and concentrated in vacuo. Purification by flash silica gel column chromatography (silica gel, 25\% ether in pentane) gave the title compound as clear oil (47.0 mg, 81\% yield, 94\% ee). IR (film) 3339, 2923, 2854, 1465, 1061, 965, $746 \mathrm{~cm}^{-1} ;{ }^{1} \mathrm{H}$ NMR (400 MHz, $\left.\mathrm{CDCl}_{3}\right) \delta$ 7.40-7.38 (m, 2H, $o$-aryl $\mathrm{H}), 7.32(\mathrm{t}, 2 \mathrm{H}, J=8.0 \mathrm{~Hz}, m$-aryl $\mathbf{H}), 7.24(\mathrm{tt}, 1 \mathrm{H}, J=8.0,1.8 \mathrm{~Hz}, p$-aryl H), 6.50 (d, $1 \mathrm{H}, J=15.9 \mathrm{~Hz}, \mathrm{CH}=\mathrm{CH}), 6.00(\mathrm{dd}, 1 \mathrm{H}, J=15.9,9.2 \mathrm{~Hz}, \mathrm{CH}=\mathrm{CH}), 3.66(\mathrm{dd}, 1 \mathrm{H}, J=$ 10.6, 5.2 Hz HOCH $\left.\mathrm{H}_{\mathrm{b}}-\mathrm{CH}\right), 3.51$ (dd, $\left.1 \mathrm{H}, J=10.6,8.4 \mathrm{~Hz}, \mathrm{HOCH}_{\mathrm{a}} \mathbf{H}_{\mathrm{b}}-\mathrm{CH}\right), 2.40$ (m, $\left.1 \mathrm{H}, \mathrm{HOCH}_{\mathrm{a}} \mathrm{H}_{\mathbf{b}}-\mathrm{CH}\right), 1.61$ (s, 1H, HO-), 1.55-1.39 (m, 1H), 1.37-1.20 (m, 11H, -CH $\left.2^{-}\right)$, 
$0.89\left(\mathrm{t}, 3 \mathrm{H}, \quad J=6.9 \mathrm{~Hz},-\mathrm{CH}_{3}\right) ;{ }^{13} \mathrm{C} \mathrm{NMR}\left(100 \mathrm{MHz}, \mathrm{CDCl}_{3}\right) \delta 137.1,132.4,131.6$, 128.5, 127.3, 126.1, 66.1, 46.4, 31.7, 31.2, 29.4, 27.1, 22.6, 14.0; HRMS (ESI-TOF) exact mass calculated for $[\mathrm{MH}]^{+\bullet}\left(\mathrm{C}_{16} \mathrm{H}_{25} \mathrm{O}\right)$ requires $\mathrm{m} / \mathrm{z}$, 233.19, found $\mathrm{m} / \mathrm{z}$ 233.1906; $[\alpha]_{D}=-21.2\left(\mathrm{c}=0.7, \mathrm{CH}_{2} \mathrm{Cl}_{2}\right)$. The enantiomeric excess was determined on by SFC analysis using a Chiralcel AD-H column $\left(20 \% \mathrm{MeOH}\right.$, isocratic, 100 bar, $35{ }^{\circ} \mathrm{C}$ oven, flow $=4.0 \mathrm{~mL} / \mathrm{min}) ;(R)$ isomer $\mathrm{t}_{\mathrm{r}}=2.82 \mathrm{~min},(S)$ isomer $\mathrm{t}_{\mathrm{r}}=3.09 \mathrm{~min}$.

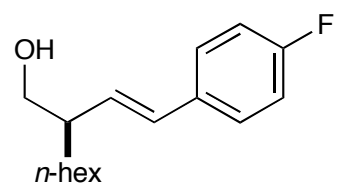

(R)-2-(4-fluorostyryl)octanol (Table 2, entry 2). Prepared according to the general procedure using DME with 1-octanal and potassium trans-4fluorostyryltrifluoroborate. To a 2 dram vial equipped with a Teflon septum and a magnetic stir bar was added the $\mathrm{BF}_{3} \mathrm{~K}$ salt (171 mg, 0.75 mmol, 3.0 equiv.), (2S,5S)-5benzyl-2-tert-butyl-3-methylimidazolidin-4-one/ trifluoroacetic acid salt (18 mg, 0.05 mmol, 0.20 eq), CAN (342 mg, 0.625 mmol, 2.5 equiv.), and $\mathrm{NaHCO}_{3}(42 \mathrm{mg}, 0.5 \mathrm{mmol}$, 2.0 equiv.). The vial was then cooled to $-78{ }^{\circ} \mathrm{C}$ before DME $(1.0 \mathrm{~mL})$ and $\mathrm{H}_{2} \mathrm{O}(1.8 \mathrm{mg}$, $1.0 \mathrm{mmol}, 4$ equiv.) was added to the pre-cooled solid mixture. The reaction mixture was then carefully degassed through alternating vacuum evacuation and charging the vessel with argon (3X). Aldehyde (32 mg, $0.25 \mathrm{mmol}, 1.0$ equiv.) was added after degassing of the reaction mixture and the reaction vial was moved and placed in $-50{ }^{\circ} \mathrm{C}$ cryocool. After $24 \mathrm{~h}$, the reaction was quenched cold with diethyl ether and stirred for 15 minutes during which precipitation of creamy white solid was observed. The reaction was then filtered through an iatrobeads plug and concentrated in vacuo $(\sim 1 \mathrm{~mL})$. The crude oil was directly diluted with DCM and EtOH (DCM : EtOH $=10 \mathrm{~mL}: 1 \mathrm{~mL})$ and $\mathrm{NaBH}_{4}(10$ equiv.) was added. Upon complete consumption of the desired aldehyde, as indicated by TLC analysis, saturated $\mathrm{NH}_{4} \mathrm{Cl}(10 \mathrm{~mL})$ was added to the reaction mixture to quench the excess $\mathrm{NaBH}_{4}$. The mixture was then extracted with DCM (3 X $\left.20 \mathrm{~mL}\right)$. Combined organic layers werewashed with $\mathrm{H}_{2} \mathrm{O}(20 \mathrm{~mL})$, brine $(20 \mathrm{~mL})$, dried over $\mathrm{MgSO}_{4}$ and 
concentrated in vacuo. Purification by flash silica gel column chromatography (silica gel, $25 \%$ ether in pentane) gave the title compound as clear oil ( $39.4 \mathrm{mg}, 63 \%$ yield, $93 \%$ ee). IR (film) 3336, 2924, 1602, 1550, 1466, 1228, 1036, 966, $813 \mathrm{~cm}^{-1}$; ${ }^{1} \mathrm{H}$ NMR (400 MHz, $\left.\mathrm{CDCl}_{3}\right) \delta 7.34\left(\mathrm{dd}, 2 \mathrm{H}, J_{\mathrm{H}-\mathrm{H}}=8.7,7.0 \mathrm{~Hz}, J_{\mathrm{H}-\mathrm{F}}=5.0 \mathrm{~Hz}, m-\operatorname{aryl~H}\right), 7.32\left(\mathrm{t}, 2 \mathrm{H}, J_{\mathrm{H}-\mathrm{H}}=8.7\right.$ $\mathrm{Hz}, J_{\mathrm{H}-\mathrm{F}}=4.4 \mathrm{~Hz}, o$-aryl $\left.\mathbf{H}\right), 6.45(\mathrm{~d}, 1 \mathrm{H}, J=15.9 \mathrm{~Hz}, \mathrm{CH}=\mathrm{CH}-\mathrm{Ph}), 5.91(\mathrm{dd}, 1 \mathrm{H}, J=$ $15.9,8.8 \mathrm{~Hz}, \mathrm{Ph}-\mathrm{CH}=\mathrm{CH}), 3.68-3.62\left(\mathrm{~m}, 1 \mathrm{H}, \mathrm{HOCH} \mathrm{H}_{\mathrm{a}} \mathrm{H}_{\mathrm{b}}-\mathrm{CH}\right), 3.51(\mathrm{dt}, 1 \mathrm{H}, J=8.4,3.6$ $\left.\mathrm{Hz}, \mathrm{HOCH}_{\mathrm{a}} \mathbf{H}_{\mathbf{b}}-\mathrm{CH}\right), 2.38\left(\mathrm{~m}, 1 \mathrm{H}, \mathrm{HOCH}_{\mathrm{a}} \mathrm{H}_{\mathbf{b}}-\mathbf{C H}\right), 1.49-1.47\left(\mathrm{~m}, 2 \mathrm{H},-\mathrm{CH}_{2}-\right), 1.37-1.20$ (m, 9H, - $\left.\mathrm{CH}_{2}-, \mathbf{H O}-\right), 0.88$ (t, $\left.3 \mathrm{H}, \quad J=6.8 \mathrm{~Hz}-\mathrm{CH}_{3}\right) ;{ }^{13} \mathrm{C} \mathrm{NMR}\left(100 \mathrm{MHz}, \mathrm{CDCl}_{3}\right) \delta$ $162.1\left(\mathrm{~d}, J_{\mathrm{C}-\mathrm{F}}=233 \mathrm{~Hz}\right), 133.3,131.4,131.1,127.6\left(\mathrm{~d}, J_{\mathrm{C}-\mathrm{F}}=7.7 \mathrm{~Hz}\right), 115.4\left(\mathrm{~d}, J_{\mathrm{C}-\mathrm{F}}=22\right.$ Hz), 66.1, 46.4, 31.8, 31.1, 29.4, 27.1, 22.6, 14.0; HRMS (ESI-TOF) exact mass calculated for $[\mathrm{MH}]^{+\bullet}\left(\mathrm{C}_{16} \mathrm{H}_{23} \mathrm{FO}\right)$ requires $m / z$ 251.1806, found $\mathrm{m} / \mathrm{z} 251.1808 ;[\alpha]_{\mathrm{D}}=-25.0$ $\left(\mathrm{c}=1.35, \mathrm{CH}_{2} \mathrm{Cl}_{2}\right)$. The enantiomeric excess was determined on by SFC analysis using a Chiralcel AD-H column (5\% to $15 \%$ Isopropyl alcohol, linear gradient, 100 bar, $35{ }^{\circ} \mathrm{C}$ oven, flow $=4.0 \mathrm{~mL} / \mathrm{min}) ;(R)$ isomer $\mathrm{t}_{\mathrm{r}}=5.16 \mathrm{~min},(S)$ isomer $\mathrm{t}_{\mathrm{r}}=5.60 \mathrm{~min}$.

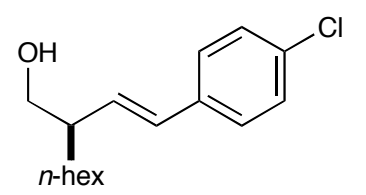

(R)-2-(4-chlorostyryl)octanol (Table 2, entry 3). Prepared according to the general procedure using DME with 1-octanal and potassium trans-4-chlorostyryltrifluoroborate. To a 2 dram vial equipped with a Teflon septum and a magnetic stir bar was added the $\mathrm{BF}_{3} \mathrm{~K}$ salt (183 mg, $0.75 \mathrm{mmol}, 3.0$ equiv.), (2S,5S)-5-benzyl-2-tertbutyl-3-methylimidazolidin-4-one/ trifluoroacetic acid salt (18 mg, $0.05 \mathrm{mmol}, 0.20 \mathrm{eq}$ ), CAN (342 mg, $0.625 \mathrm{mmol}, 2.5$ equiv.), and $\mathrm{NaHCO}_{3}(42 \mathrm{mg}, 0.5 \mathrm{mmol}, 2.0$ equiv.). The vial was then cooled to $-78{ }^{\circ} \mathrm{C}$ before DME $(1.0 \mathrm{~mL})$ and $\mathrm{H}_{2} \mathrm{O}(1.8 \mathrm{mg}, 1.0 \mathrm{mmol}, 4$ equiv.) was added to the pre-cooled solid mixture. The reaction mixture was then carefully degassed through alternating vacuum evacuation and charging the vessel with argon (3X). Aldehyde (32 mg, $0.25 \mathrm{mmol}, 1.0$ equiv.) was added after degassing of the reaction mixture and the reaction vial was moved and placed in $-50{ }^{\circ} \mathrm{C}$ cryocool. After 24 
$\mathrm{h}$, the reaction was quenched cold with diethyl ether and stirred for 15 minutes during which precipitation of creamy white solid was observed. The reaction was then filtered through an iatrobeads plug and concentrated in vacuo $(\sim 1 \mathrm{~mL})$. The crude oil was directly diluted with DCM and EtOH (DCM : EtOH $=10 \mathrm{~mL}: 1 \mathrm{~mL})$ and $\mathrm{NaBH}_{4}(10$ equiv.) was added. Upon complete consumption of the desired aldehyde, as indicated by TLC analysis, saturated $\mathrm{NH}_{4} \mathrm{Cl}(10 \mathrm{~mL})$ was added to the reaction mixture to quench the excess $\mathrm{NaBH}_{4}$. The mixture was then extracted with DCM (3 X $\left.20 \mathrm{~mL}\right)$. Combined organic layers were washed with $\mathrm{H}_{2} \mathrm{O}(20 \mathrm{~mL})$, brine $(20 \mathrm{~mL})$, dried over $\mathrm{MgSO}_{4}$ and concentrated in vасио. Purification by flash silica gel column chromatography (silica gel, $25 \%$ ether in pentane) gave the title compound as clear oil (51.4 mg, $77 \%$ yield, $95 \%$ ee). IR (film) 3344, 2924, 2854, 1602, 1490, 1465, 1228, 1090, 1012, 966, $813 \mathrm{~cm}^{-1}$; ${ }^{1} \mathrm{H}$ NMR $\left(400 \mathrm{MHz}, \mathrm{CDCl}_{3}\right) \delta$ 7.32-7.26 (m, 4H, aryl H), $6.44(\mathrm{~d}, 1 \mathrm{H}, J=15.9 \mathrm{~Hz}, \mathrm{CH}=\mathrm{CH}), 5.98$ (dd, $1 \mathrm{H}, J=15.9,9.2 \mathrm{~Hz}, \mathrm{CH}=\mathrm{CH}), 3.66\left(\mathrm{~m}, 1 \mathrm{H}, J=12.7,7.6,5.2 \mathrm{~Hz} \mathrm{HOCH}_{\mathrm{a}} \mathrm{H}_{\mathrm{b}}-\mathrm{CH}\right)$, $3.51\left(\mathrm{ddd}, 1 \mathrm{H}, J=12.3,8.0,4.1 \mathrm{~Hz}, \mathrm{HOCH}_{\mathrm{a}} \mathbf{H}_{\mathbf{b}}-\mathrm{CH}\right), 2.38\left(\mathrm{~m}, 1 \mathrm{H}, \mathrm{HOCH}_{\mathrm{a}} \mathrm{H}_{\mathbf{b}}-\mathrm{CH}\right), 1.49-$ $1.44\left(\mathrm{~m}, 1 \mathrm{H},-\mathrm{CH}_{2^{-}}\right), 1.45\left(\mathrm{dd}, 1 \mathrm{H}, J=8.0,4.4 \mathrm{~Hz},-\mathrm{CH}_{2^{-}}\right), 1.40-1.20$ (m, 9H, - $\mathrm{CH}_{2^{-}}, \mathbf{H O}-$ ), $0.88\left(\mathrm{t}, 3 \mathrm{H}, \quad J=7.2 \mathrm{~Hz}-\mathrm{CH}_{3}\right) ;{ }^{13} \mathrm{C} \mathrm{NMR}\left(100 \mathrm{MHz}, \mathrm{CDCl}_{3}\right) \delta$ 135.6, 132.8, 132.4, 131.0, 128.6, 127.3, 66.0, 46.4, 31.7, 31.1, 29.3, 27.1, 22.6, 14.0; HRMS (ESI-TOF) exact mass calculated for $[\mathrm{MH}]^{+\bullet}\left(\mathrm{C}_{16} \mathrm{H}_{24} \mathrm{ClO}\right)$ requires $m / z$ 267.151, found $m / z$ 267.1510; $[\alpha]_{D}=-14.8\left(\mathrm{c}=1.7, \mathrm{CH}_{2} \mathrm{Cl}_{2}\right)$. The enantiomeric excess was determined on by SFC analysis using a Chiralcel AD-H column (5\% to 50\% $\mathrm{MeOH}$, linear gradient, 100 bar, 35 ${ }^{\circ} \mathrm{C}$ oven, flow $\left.=4.0 \mathrm{~mL} / \mathrm{min}\right) ;(R)$ isomer $\mathrm{t}_{\mathrm{r}}=5.10 \mathrm{~min},(S)$ isomer $\mathrm{t}_{\mathrm{r}}=5.73 \mathrm{~min}$.

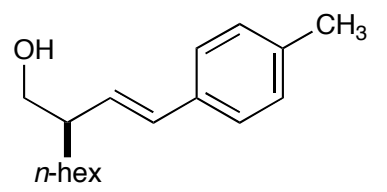

(R)-2-(4-methylstyryl)octanol (Table 2, entry 4). Prepared according to the general procedure using DME with 1-octanal and potassium trans-4methylstyryltrifluoroborate. To a 2 dram vial equipped with a Teflon septum and a magnetic stir bar was added the $\mathrm{BF}_{3} \mathrm{~K}$ salt (168 mg, $0.75 \mathrm{mmol}, 3.0$ equiv.), (2S,5S)-5- 
benzyl-2-tert-butyl-3-methylimidazolidin-4-one/ trifluoroacetic acid salt $(18 \mathrm{mg}, 0.05$ mmol, 0.20 eq), CAN (342 mg, $0.625 \mathrm{mmol}, 2.5$ equiv.), and $\mathrm{NaHCO}_{3}(42 \mathrm{mg}, 0.5 \mathrm{mmol}$, 2.0 equiv.). The vial was then cooled to $-78{ }^{\circ} \mathrm{C}$ before DME $(1.0 \mathrm{~mL})$ and $\mathrm{H}_{2} \mathrm{O}(1.8 \mathrm{mg}$, $1.0 \mathrm{mmol}, 4$ equiv.) was added to the pre-cooled solid mixture. The reaction mixture was then carefully degassed through alternating vacuum evacuation and charging the vessel with argon (3X). Aldehyde (32 mg, $0.25 \mathrm{mmol}, 1.0$ equiv.) was added after degassing of the reaction mixture and the reaction vial was moved and placed in $-50^{\circ} \mathrm{C}$ cryocool. After $24 \mathrm{~h}$, the reaction was quenched cold with diethyl ether and stirred for 15 minutes during which precipitation of creamy white solid was observed. The reaction was then filtered through an iatrobeads plug and concentrated in vacuo $(\sim 1 \mathrm{~mL})$. The crude oil was directly diluted with DCM and EtOH (DCM : EtOH $=10 \mathrm{~mL}: 1 \mathrm{~mL})$ and $\mathrm{NaBH}_{4}(10$ equiv.) was added. Upon complete consumption of the desired aldehyde, as indicated by TLC analysis, saturated $\mathrm{NH}_{4} \mathrm{Cl}(10 \mathrm{~mL})$ was added to the reaction mixture to quench the excess $\mathrm{NaBH}_{4}$. The mixture was then extracted with DCM (3 X $\left.20 \mathrm{~mL}\right)$. Combined organic layers were washed with $\mathrm{H}_{2} \mathrm{O}(20 \mathrm{~mL})$, brine $(20 \mathrm{~mL})$, dried over $\mathrm{MgSO}_{4}$ and concentrated in vacuo. Purification by flash silica gel column chromatography (silica gel, $25 \%$ ether in pentane) gave the title compound as clear oil ( $46.2 \mathrm{mg}, 76 \%$ yield, $92 \%$ ee). IR (film) 3372, 2954, 2855, 1513, 1465, 1062, 967, $799 \mathrm{~cm}^{-1}$; ${ }^{1} \mathrm{H}$ NMR (400 MHz, $\left.\mathrm{CDCl}_{3}\right) \delta 7.29(\mathrm{~d}, 2 \mathrm{H}, J=8.3 \mathrm{~Hz}, o$-aryl H), $7.13(\mathrm{~d}, 2 \mathrm{H}, J=8.2 \mathrm{~Hz}, m$-aryl H), 6.47 (d, $1 \mathrm{H}, J=15.9 \mathrm{~Hz}, \mathrm{CH}=\mathrm{CH}-\mathrm{Ph}), 5.93(\mathrm{dd}, 1 \mathrm{H}, J=15.9,9.2 \mathrm{~Hz}, \mathrm{Ph}-\mathrm{CH}=\mathrm{CH}), 3.64(\mathrm{dd}, 1 \mathrm{H}$, $\left.J=10.4,5.2 \mathrm{~Hz} \mathrm{HOCH}_{\mathrm{a}} \mathrm{H}_{\mathrm{b}}-\mathrm{CH}\right), 3.50\left(\mathrm{dd}, 1 \mathrm{H}, J=10.4,8.0 \mathrm{~Hz}, \mathrm{HOCH}_{\mathrm{a}} \mathbf{H}_{\mathrm{b}}-\mathrm{CH}\right), 2.40-$ $2.33\left(\mathrm{~m}, 1 \mathrm{H}, \mathrm{HOCH}_{\mathrm{a}} \mathrm{H}_{\mathrm{b}}-\mathrm{CH}\right), 2.35\left(\mathrm{~s}, 3 \mathrm{H}, \mathrm{Ar}-\mathrm{CH}_{3}\right), 1.49-1.48\left(\mathrm{~m}, 1 \mathrm{H},-\mathrm{CH}_{2}-\right), 1.38-1.28$ (m, 9H, -CH $\left.2^{-}, \mathbf{H O}-\right), 0.89$ (t, 3H, $\left.J=6.7 \mathrm{~Hz}-\mathrm{CH}_{3}\right) ;{ }^{13} \mathrm{C}$ NMR $\left(100 \mathrm{MHz}, \mathrm{CDCl}_{3}\right) \delta$ 137.1, 134.3, 132.3, 130.5, 129.2, 126.0, 66.1, 46.4, 31.7, 31.2, 29.4, 27.1, 22.6, 21.1, 14.1; HRMS (ESI-TOF) exact mass calculated for $[\mathrm{MH}]^{+*}\left(\mathrm{C}_{17} \mathrm{H}_{27} \mathrm{O}\right)$ requires $\mathrm{m} / \mathrm{z}$ 247.2056, found $m / z$ 247.2059; $[\alpha]_{\mathrm{D}}=-26.1\left(\mathrm{c}=1.33, \mathrm{CH}_{2} \mathrm{Cl}_{2}\right)$. The enantiomeric excess was determined on by SFC analysis using a Chiralcel AS-H column (5\% to $50 \% \mathrm{MeOH}$, linear gradient, 100 bar, $35{ }^{\circ} \mathrm{C}$ oven, flow $\left.=4.0 \mathrm{~mL} / \mathrm{min}\right) ;(R)$ isomer $\mathrm{t}_{\mathrm{r}}=2.40 \mathrm{~min},(S)$ isomer $\mathrm{t}_{\mathrm{r}}=2.52 \mathrm{~min}$. 


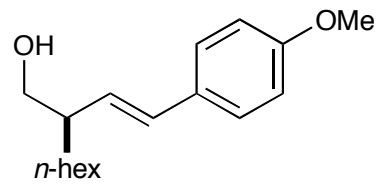

(R)-2-(4-methoxystyryl)octanol (Table 2, entry 5). Prepared according to the general procedure using DME with 1-octanal and potassium trans-4-methoxy styryltrifluoroborate. To a 2 dram vial equipped with a Teflon septum and a magnetic stir bar was added the $\mathrm{BF}_{3} \mathrm{~K}$ salt (158 mg, $0.75 \mathrm{mmol}, 3.0$ equiv.), (2S,5S)-5-benzyl-2-tertbutyl-3-methylimidazolidin-4-one/ trifluoroacetic acid salt (18 mg, $0.05 \mathrm{mmol}, 0.20 \mathrm{eq})$, CAN (342 mg, 0.625 mmol, 2.5 equiv.), and $\mathrm{NaHCO}_{3}$ (42 mg, $0.5 \mathrm{mmol}, 2.0$ equiv.). The vial was then cooled to $-78{ }^{\circ} \mathrm{C}$ before DME $(1.0 \mathrm{~mL})$ and $\mathrm{H}_{2} \mathrm{O}(1.8 \mathrm{mg}, 1.0 \mathrm{mmol}, 4$ equiv.) was added to the pre-cooled solid mixture. The reaction mixture was then carefully degassed through alternating vacuum evacuation and charging the vessel with argon (3X). Aldehyde (32 mg, $0.25 \mathrm{mmol}, 1.0$ equiv.) was added after degassing of the reaction mixture and the reaction vial was moved and placed in $-50{ }^{\circ} \mathrm{C}$ cryocool. After 24 $\mathrm{h}$, the reaction was quenched cold with diethyl ether and stirred for 15 minutes during which precipitation of creamy white solid was observed. The reaction was then filtered through an iatrobeads plug and concentrated in vacuo $(\sim 1 \mathrm{~mL})$. The crude oil was directly diluted with $\mathrm{DCM}$ and EtOH (DCM : EtOH $=10 \mathrm{~mL}: 1 \mathrm{~mL})$ and $\mathrm{NaBH}_{4}(10$ equiv.) was added. Upon complete consumption of the desired aldehyde, as indicated by TLC analysis, saturated $\mathrm{NH}_{4} \mathrm{Cl}(10 \mathrm{~mL})$ was added to the reaction mixture to quench the excess $\mathrm{NaBH}_{4}$. The mixture was then extracted with DCM (3 X $\left.20 \mathrm{~mL}\right)$. Combined organic layers were washed with $\mathrm{H}_{2} \mathrm{O}(20 \mathrm{~mL})$, brine $(20 \mathrm{~mL})$, dried over $\mathrm{MgSO}_{4}$ and concentrated in vacuo. Purification by flash silica gel column chromatography (silica gel, $25 \%$ ether in pentane) gave the title compound as clear oil ( $40.0 \mathrm{mg}, 61 \%$ yield, $95 \%$ ee). IR (film) 3425, 2926, 1607, 1510, 1464, 1230, 1174, 1034, 966, $815 \mathrm{~cm}^{-1} ;{ }^{1} \mathrm{H}$ NMR (400 $\left.\mathrm{MHz} \mathrm{CDCl}_{3}\right) \delta 7.32(\mathrm{~d}, 2 \mathrm{H}, J=8.8 \mathrm{~Hz}, o$-aryl H), $6.86(\mathrm{~d}, 2 \mathrm{H}, J=8.8 \mathrm{~Hz}, m$-aryl H), $6.44(\mathrm{~d}, 1 \mathrm{H}, J=15.9 \mathrm{~Hz}, \mathrm{CH}=\mathrm{CH}-\mathrm{Ph}), 5.84(\mathrm{dd}, 1 \mathrm{H}, J=15.9,8.8 \mathrm{~Hz}, \mathrm{Ph}-\mathrm{CH}=\mathrm{CH}), 3.82$ $\left(\mathrm{s}, 3 \mathrm{H}, \operatorname{Ar}-\mathrm{OCH}_{3}\right), 3.67-3.61\left(\mathrm{~m}, 1 \mathrm{H}, \mathrm{HOCH}_{\mathrm{a}} \mathrm{H}_{\mathrm{b}}-\mathrm{CH}\right), 3.52-3.45\left(\mathrm{~m}, 1 \mathrm{H}, \mathrm{HOCH}_{\mathrm{a}} \mathbf{H}_{\mathrm{b}}-\mathrm{CH}\right)$, 
2.38-2.34 (m, 1H, $\left.\mathrm{HOCH}_{\mathrm{a}} \mathrm{H}_{\mathbf{b}}-\mathrm{CH}\right), 1.50-1.48\left(\mathrm{~m}, 1 \mathrm{H},-\mathrm{CH}_{2}^{-}\right), 1.43-1.40\left(\mathrm{~m}, 1 \mathrm{H},-\mathrm{CH}_{2^{-}}\right)$, 1.35-1.18 (m, 9H, - $\mathrm{CH}_{2}-$, HO- $), 0.84\left(\mathrm{t}, 3 \mathrm{H}, \quad J=6.8 \mathrm{~Hz}-\mathrm{CH}_{3}\right) ;{ }^{13} \mathrm{C}$ NMR $(100 \mathrm{MHz}$, $\left.\mathrm{CDCl}_{3}\right) \delta 158.6,131.5,129.6,129.0,126.9,113.6,65.8,55.0,46.1,31.4,30.9,29.0,26.8$, 22.3, 13.7; HRMS (ESI-TOF) exact mass calculated for $[\mathrm{MH}]^{+\bullet}\left(\mathrm{C}_{17} \mathrm{H}_{27} \mathrm{O}_{2}\right)$ requires $\mathrm{m} / \mathrm{z}$ 263.2005, found $m / z$ 263.1998; $[\alpha]_{D}=-25.2\left(c=1.0, \mathrm{CH}_{2} \mathrm{Cl}_{2}\right)$. The enantiomeric excess was determined on by SFC analysis using a Chiralcel AD-H column $(25 \% \mathrm{MeOH}$, isocratic, 100 bar, $35^{\circ} \mathrm{C}$ oven, flow $\left.=4.0 \mathrm{~mL} / \mathrm{min}\right) ;(R)$ isomer $\mathrm{t}_{\mathrm{r}}=4.43 \mathrm{~min},(S)$ isomer $\mathrm{t}_{\mathrm{r}}$ $=6.16 \mathrm{~min}$.

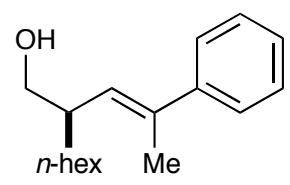

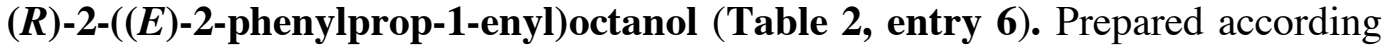
to the general procedure using DME with 1-octanal and potassium trans- $\alpha$-methyl styryl trifluoroborate. To a 2 dram vial equipped with a Teflon septum and a magnetic stir bar was added the $\mathrm{BF}_{3} \mathrm{~K}$ salt (168 mg, $0.75 \mathrm{mmol}, 3.0$ equiv.), (2S,5S)-5-benzyl-2-tert-butyl3-methylimidazolidin-4-one/ trifluoroacetic acid salt (18 mg, $0.05 \mathrm{mmol}, 0.20 \mathrm{eq}$ ), CAN (342 mg, 0.625 mmol, 2.5 equiv.), and $\mathrm{NaHCO}_{3}$ (42 mg, $0.5 \mathrm{mmol}, 2.0$ equiv.). The vial was then cooled to $-78{ }^{\circ} \mathrm{C}$ before DME (1.0 mL) and $\mathrm{H}_{2} \mathrm{O}(1.8 \mathrm{mg}, 1.0 \mathrm{mmol}, 4$ equiv.) was added to the pre-cooled solid mixture. The reaction mixture was then carefully degassed through alternating vacuum evacuation and charging the vessel with argon (3X). Aldehyde (32 mg, $0.25 \mathrm{mmol}, 1.0$ equiv.) was added after degassing of the reaction mixture and the reaction vial was moved and placed in $-50{ }^{\circ} \mathrm{C}$ cryocool. After $24 \mathrm{~h}$, the reaction was quenched cold with diethyl ether and stirred for 15 minutes during which precipitation of creamy white solid was observed. The reaction was then filtered through an iatrobeads plug and concentrated in vacuo $(\sim 1 \mathrm{~mL})$. The crude oil was directly diluted with DCM and EtOH (DCM : EtOH = $10 \mathrm{~mL}: 1 \mathrm{~mL})$ and $\mathrm{NaBH}_{4}$ (10 equiv.) was added. Upon complete consumption of the desired aldehyde, as indicated by TLC analysis, saturated $\mathrm{NH}_{4} \mathrm{Cl}(10 \mathrm{~mL})$ was added to the reaction mixture to quench the excess $\mathrm{NaBH}_{4}$. 
The mixture was then extracted with DCM (3 X $20 \mathrm{~mL}$ ). Combined organic layers were washed with $\mathrm{H}_{2} \mathrm{O}(20 \mathrm{~mL})$, brine $(20 \mathrm{~mL})$, dried over $\mathrm{MgSO}_{4}$ and concentrated in vacuo. Purification by flash silica gel column chromatography (silica gel, 25\% ether in pentane) gave the title compound as clear oil (57.3 mg, 93\% yield, 94\% ee). IR (film) 3326, 2923, 1493, 1445, 1379, 1057, 1025, 766, $696 \mathrm{~cm}^{-1}$; ${ }^{1} \mathrm{H}$ NMR (400 MHz, $\mathrm{CDCl}_{3}$ ) $\delta$ 7.43-7.40 $(\mathrm{m}, 2 \mathrm{H}, o$-aryl H), $7.34(\mathrm{t}, 2 \mathrm{H}, J=7.1 \mathrm{~Hz}, m$-aryl H), $7.26(\mathrm{~m}, 1 \mathrm{H}, p$-aryl H), 5.52 (dq, $1 \mathrm{H}, J=11.2,1.6 \mathrm{~Hz}, \mathrm{CH}=\mathrm{CH}), 3.65\left(\mathrm{~m}, 1 \mathrm{H}, \mathrm{HOCH}_{\mathrm{a}} \mathrm{H}_{\mathrm{b}}-\mathrm{CH}\right), 3.48(\mathrm{t}, 1 \mathrm{H}, J=8.3 \mathrm{~Hz}$, $\left.\mathrm{HOCH}_{\mathrm{a}} \mathbf{H}_{\mathrm{b}}-\mathrm{CH}\right), 2.76-2.70\left(\mathrm{~m}, 1 \mathrm{H}, \mathrm{HOCH}_{\mathrm{a}} \mathrm{H}_{\mathrm{b}}-\mathrm{CH}\right), 2.11\left(\mathrm{~d}, 3 \mathrm{H}, J=1.6 \mathrm{~Hz},-\mathbf{C H}_{3}\right), 1.56-$ 1.48 (m, 1H, - $\left.\mathbf{C H}_{2}-\right), 1.43-1.39$ (m, 1H, - $\mathbf{C H}_{2}^{-}$), 1.38-1.18 (m, 9H, - $\left.\mathbf{C H}_{2^{-}}, \mathbf{H O}-\right), 0.89$ (t, $\left.3 \mathrm{H}, J=6.8 \mathrm{~Hz},-\mathrm{CH}_{3}\right) ;{ }^{13} \mathrm{C} \mathrm{NMR}\left(100 \mathrm{MHz}, \mathrm{CDCl}_{3}\right) \delta 143.5,138.0,129.9,128.2,126.9$, 125.7, 66.7, 41.9, 31.84, 31.80, 29.5, 27.2, 22.6, 16.6, 14.1 ; HRMS (ESI-TOF) exact mass calculated for $[\mathrm{MH}]^{+\bullet}\left(\mathrm{C}_{17} \mathrm{H}_{27} \mathrm{O}\right)$ requires $\mathrm{m} / z 247.2056$, found $\mathrm{m} / z$ 247.2057; $[\alpha]_{\mathrm{D}}=$ $4.3\left(\mathrm{c}=0.9, \mathrm{CH}_{2} \mathrm{Cl}_{2}\right)$. The enantiomeric excess was determined on by SFC analysis using a Chiralcel $\mathrm{AD}-\mathrm{H}$ column ( $5 \%$ to $50 \% \mathrm{MeOH}$, linear gradient, $100 \mathrm{bar}, 35{ }^{\circ} \mathrm{C}$ oven, flow $=4.0 \mathrm{~mL} / \mathrm{min}) ;(S)$ isomer $\mathrm{t}_{\mathrm{r}}=2.61 \mathrm{~min},(R)$ isomer $\mathrm{t}_{\mathrm{r}}=3.72 \mathrm{~min}$.

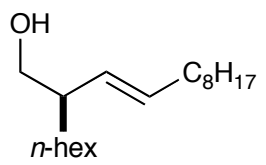

$(R, E)$-2-hexyldodec-3-enol (Table 2, entry 7). Prepared according to the general procedure using acetone with 1-octanal and potassium trans-1-decenyltrifluoroborate. To a 2 dram vial equipped with a Teflon septum and a magnetic stir bar was added the $\mathrm{BF}_{3} \mathrm{~K}$ salt $\quad(154 \mathrm{mg}, \quad 0.625 \mathrm{mmol}, \quad 5.0 \quad$ equiv.), (2S,5S)-5-benzyl-2-tert-butyl-3methylimidazolidin-4-one/ trifluoroacetic acid salt $(9.0 \mathrm{mg}, 0.025 \mathrm{mmol}, 0.20 \mathrm{eq})$, CAN (171 mg, $0.312 \mathrm{mmol}, 2.5$ equiv.), and $\mathrm{NaHCO}_{3}(21 \mathrm{mg}, 0.25 \mathrm{mmol}, 2.0$ equiv.). The vial was then cooled to $-78{ }^{\circ} \mathrm{C}$ before acetone $(2.0 \mathrm{~mL})$ and $\mathrm{H}_{2} \mathrm{O}(0.9 \mathrm{mg}, 0.5 \mathrm{mmol}, 4$ equiv. $)$ was added to the pre-cooled solid mixture. The reaction mixture was then carefully degassed through alternating vacuum evacuation and charging the vessel with argon (3X). Aldehyde (16 mg, $0.125 \mathrm{mmol}, 1.0$ equiv.) was added after degassing of the reaction mixture and the reaction vial was moved and placed in $-50{ }^{\circ} \mathrm{C}$ cryocool. After 24 
$\mathrm{h}$, the reaction was quenched cold with diethyl ether and stirred for 15 minutes during which precipitation of creamy white solid was observed. The reaction was then filtered through an iatrobeads plug and concentrated in vacuo $(\sim 1 \mathrm{~mL})$. The crude oil was directly diluted with DCM and EtOH (DCM : EtOH $=10 \mathrm{~mL}: 1 \mathrm{~mL})$ and $\mathrm{NaBH}_{4}(10$ equiv.) was added. Upon complete consumption of the desired aldehyde, as indicated by TLC analysis, saturated $\mathrm{NH}_{4} \mathrm{Cl}(10 \mathrm{~mL})$ was added to the reaction mixture to quench the excess $\mathrm{NaBH}_{4}$. The mixture was then extracted with DCM (3 X $\left.20 \mathrm{~mL}\right)$. Combined organic layers were washed with $\mathrm{H}_{2} \mathrm{O}(20 \mathrm{~mL})$, brine $(20 \mathrm{~mL})$, dried over $\mathrm{MgSO}_{4}$ and concentrated in vacuo. Purification by flash silica gel column chromatography (silica gel, $25 \%$ ether in pentane) gave the title compound as clear oil (27.5 mg, $82 \%$ yield, $89 \%$ ee). IR (film) 3336, 2955, 2920, 2853, 1465, 1378, 1031, 968, 722 $\mathrm{cm}^{-1}$; ${ }^{1} \mathrm{H}$ NMR (400 MHz, $\left.\mathrm{CDCl}_{3}\right) \delta 5.54(\mathrm{dt}, 1 \mathrm{H}, J=15.1,6.8 \mathrm{~Hz}, \mathrm{CH}=\mathrm{CH}), 5.13$ (ddt, $1 \mathrm{H}, J=15.5,9.2,1.6 \mathrm{~Hz}$, $\mathrm{CH}=\mathrm{CH}$ ), $3.53\left(\mathrm{ddd}, 1 \mathrm{H}, J=10.4,8.4,4.8 \mathrm{~Hz}, \mathrm{HOC} \mathbf{H}_{\mathrm{a}} \mathrm{H}_{\mathrm{b}}-\mathrm{CH}\right.$ ), $3.48(\mathrm{ddd}, 1 \mathrm{H}, J=10.4$, 8.8, 3.6 Hz, HOCH $\left.\mathrm{H}_{\mathrm{b}}-\mathrm{CH}\right), 2.18\left(\mathrm{~m}, 1 \mathrm{H}, \mathrm{HOCH}_{\mathrm{a}} \mathrm{H}_{\mathbf{b}}-\mathrm{CH}\right), 2.03(\mathrm{q}, 2 \mathrm{H}, J=6.8 \mathrm{~Hz},-$ $\mathrm{CH}_{2}-$ ), 1.44 (dd, $\left.1 \mathrm{H}, J=8.4,3.6 \mathrm{~Hz},-\mathrm{CH}_{2}-\right), 1.38-1.18$ (m, 20H, -CH $\left.\mathbf{C H}^{-}, \mathbf{H O}-\right), 0.89$ (t, $\left.3 \mathrm{H}, J=6.7 \mathrm{~Hz},-\mathrm{CH}_{3}\right), 0.88\left(\mathrm{t}, 3 \mathrm{H}, J=7.1 \mathrm{~Hz},-\mathrm{CH}_{3}\right) ;{ }^{13} \mathrm{C} \mathrm{NMR}\left(100 \mathrm{MHz}, \mathrm{CDCl}_{3}\right) \delta$ 134.1, 131.2, 66.0, 46.0, 32.7, 31.9, 31.8, 31.1, 29.5, 29.4, 29.3(*2), 29.1, 27.0, 22.7(*2), 14.1(*2) ; HRMS (ESI-TOF) exact mass calculated for $[\mathrm{MH}]^{+\bullet}\left(\mathrm{C}_{18} \mathrm{H}_{37} \mathrm{O}\right)$ requires $\mathrm{m} / \mathrm{z}$ 269.2839, found $\mathrm{m} / \mathrm{z} 269.2831 ;[\alpha]_{\mathrm{D}}=-1.5\left(\mathrm{c}=1.2, \mathrm{CH}_{2} \mathrm{Cl}_{2}\right)$. The enantiomeric excess was determined on by HPLC analysis after conversion to 2-Naphtoyl derivative using a Chiralcel OD-H column (2.5\% IPA, Isocratic, 38 bar, $35^{\circ} \mathrm{C}$ oven, flow $=4.0 \mathrm{~mL} / \mathrm{min}$ ); $(S)$ isomer $\mathrm{t}_{\mathrm{r}}=25.6 \mathrm{~min},(R)$ isomer $\mathrm{t}_{\mathrm{r}}=30.3 \mathrm{~min}$.

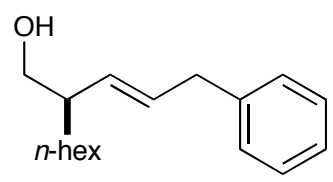

(R)-2-((E)-3-phenylprop-1-enyl)octanol (Table 2, entry 8). Prepared according to the general procedure using acetone with 1-octanal and potassium trans-3-phenyl-1- 
propeny-1-yltrifluoroborate. To a 2 dram vial equipped with a Teflon septum and a magnetic stir bar was added the $\mathrm{BF}_{3} \mathrm{~K}$ salt (140 mg, $0.625 \mathrm{mmol}, 5.0$ equiv.), (2S,5S)-5benzyl-2-tert-butyl-3-methylimidazolidin-4-one $(9.0 \mathrm{mg}, 0.025 \mathrm{mmol}, 0.20 \mathrm{eq})$, CAN (171 mg, $0.312 \mathrm{mmol}, 2.5$ equiv.), and $\mathrm{NaHCO}_{3}(21 \mathrm{mg}, 0.25 \mathrm{mmol}, 2.0$ equiv.). The vial was then cooled to $-78{ }^{\circ} \mathrm{C}$ before acetone $(2.0 \mathrm{~mL})$ and $\mathrm{H}_{2} \mathrm{O}(0.9 \mathrm{mg}, 0.5 \mathrm{mmol}, 4$ equiv. $)$ was added to the pre-cooled solid mixture. The reaction mixture was then carefully degassed through alternating vacuum evacuation and charging the vessel with argon (3X). Aldehyde (16 mg, $0.125 \mathrm{mmol}, 1.0$ equiv.) was added after degassing of the reaction mixture and the reaction vial was moved and placed in $-50{ }^{\circ} \mathrm{C}$ cryocool. After 24 $\mathrm{h}$, the reaction was quenched cold with diethyl ether and stirred for 15 minutes during which precipitation of creamy white solid was observed. The reaction was then filtered through an iatrobeads plug and concentrated in vacuo $(\sim 1 \mathrm{~mL})$. The crude oil was directly diluted with DCM and EtOH $(\mathrm{DCM}: \mathrm{EtOH}=10 \mathrm{~mL}: 1 \mathrm{~mL})$ and $\mathrm{NaBH}_{4}(10$ equiv.) was added. Upon complete consumption of the desired aldehyde, as indicated by TLC analysis, saturated $\mathrm{NH}_{4} \mathrm{Cl}(10 \mathrm{~mL})$ was added to the reaction mixture to quench the excess $\mathrm{NaBH}_{4}$. The mixture was then extracted with DCM (3 X $\left.20 \mathrm{~mL}\right)$. Combined organic layers were washed with $\mathrm{H}_{2} \mathrm{O}(20 \mathrm{~mL})$, brine $(20 \mathrm{~mL})$, dried over $\mathrm{MgSO}_{4}$ and concentrated in vacuo. Purification by flash silica gel column chromatography (silica gel, $25 \%$ ether in pentane) gave the title compound as clear oil ( $21.9 \mathrm{mg}, 71 \%$ yield, $91 \%$ ee). IR (film) 3340, 2954, 2910, 2854, 1494, 1453, 1054, 970, 743, $698 \mathrm{~cm}^{-1} ;{ }^{1} \mathrm{H}$ NMR (400 $\left.\mathrm{MHz}, \mathrm{CDCl}_{3}\right) \delta$ 7.32-7.26 (m, 2H, aryl H), 7.25-7.17 (m, 3H, aryl H), $5.72(\mathrm{~d}, 1 \mathrm{H}, J=$ $15.5 \mathrm{~Hz}, \mathrm{CH}=\mathrm{CH}), 5.28(\mathrm{dd}, 1 \mathrm{H}, J=15.5,8.7 \mathrm{~Hz}, \mathrm{CH}=\mathrm{CH}), 3.59-3.50(\mathrm{~m}, 1 \mathrm{H}$, $\left.\mathrm{HOCH}_{\mathrm{a}} \mathrm{H}_{\mathrm{b}}-\mathrm{CH}\right), 3.48-3.37\left(\mathrm{~m}, 1 \mathrm{H}, \mathrm{HOCH}_{\mathrm{a}} \mathbf{H}_{\mathrm{b}}-\mathrm{CH}\right), 3.40\left(\mathrm{~d}, 2 \mathrm{H}, J=6.3 \mathrm{~Hz},-\mathrm{CH}_{2}-\mathrm{Ar}\right)$, 2.24-2.19 (m, $\left.1 \mathrm{H}, \mathrm{HOCH}_{\mathrm{a}} \mathrm{H}_{\mathrm{b}}-\mathrm{CH}\right), 1.59-1.18\left(\mathrm{~m}, 11 \mathrm{H},-\mathrm{CH}_{2^{-}}, \mathbf{H O}-\right), 0.89(\mathrm{t}, 3 \mathrm{H}, J=6.7$ $\left.\mathrm{Hz},-\mathrm{CH}_{3}\right) ;{ }^{13} \mathrm{C} \mathrm{NMR}\left(100 \mathrm{MHz}, \mathrm{CDCl}_{3}\right) \delta 140.5,133.0,1321,128.4(* 2), 126.0,66.0$, 45.8, 39.1, 31.8, 31.0, 29.3, 27.1, 22.6, 14.1; HRMS (ESI-TOF) exact mass calculated for $[\mathrm{MH}]^{+\bullet}\left(\mathrm{C}_{17} \mathrm{H}_{27} \mathrm{O}\right)$ requires $\mathrm{m} / \mathrm{z}$ 247.2056, found $\mathrm{m} / \mathrm{z}$ 247.2055; $[\alpha]_{\mathrm{D}}=8.7(\mathrm{c}=0.65$, $\mathrm{CH}_{2} \mathrm{Cl}_{2}$ ). The enantiomeric excess was determined on by SFC analysis using a Chiralcel 
$\mathrm{OJ}-\mathrm{H}$ column $\left(5 \%\right.$ to $10 \% \mathrm{MeOH}$, linear gradient, 100 bar, $35{ }^{\circ} \mathrm{C}$ oven, flow $=4.0$ $\mathrm{mL} / \mathrm{min}) ;(R)$ isomer $\mathrm{t}_{\mathrm{r}}=2.17 \mathrm{~min},(S)$ isomer $\mathrm{t}_{\mathrm{r}}=2.34 \mathrm{~min}$.

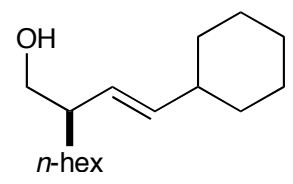

(R)-2-((E)-2-cyclohexylvinyl)octanol (Table 2, entry 9). Prepared according to the general procedure using acetone with 1-octanal and potassium trans-2cyclohexylvinyl trifluoroborate. To a 2 dram vial equipped with a Teflon septum and a magnetic stir bar was added the $\mathrm{BF}_{3} \mathrm{~K}$ salt (135 mg, $0.625 \mathrm{mmol}, 5.0$ equiv.), (2S,5S)-5benzyl-2-tert-butyl-3-methylimidazolidin-4-one (9.0 mg, $0.025 \mathrm{mmol}, 0.20 \mathrm{eq}), \mathrm{CAN}$ (171 mg, $0.312 \mathrm{mmol}, 2.5$ equiv.), and $\mathrm{NaHCO}_{3}(21 \mathrm{mg}, 0.25 \mathrm{mmol}, 2.0$ equiv.). The vial was then cooled to $-78^{\circ} \mathrm{C}$ before acetone $(2.0 \mathrm{~mL})$ and $\mathrm{H}_{2} \mathrm{O}(0.9 \mathrm{mg}, 0.5 \mathrm{mmol}, 4$ equiv. $)$ was added to the pre-cooled solid mixture. The reaction mixture was then carefully degassed through alternating vacuum evacuation and charging the vessel with argon (3X). Aldehyde (16 mg, $0.125 \mathrm{mmol}, 1.0$ equiv.) was added after degassing of the reaction mixture and the reaction vial was moved and placed in $-50{ }^{\circ} \mathrm{C}$ cryocool. After 24 $\mathrm{h}$, the reaction was quenched cold with diethyl ether and stirred for 15 minutes during which precipitation of creamy white solid was observed. The reaction was then filtered through an iatrobeads plug and concentrated in vacuo $(\sim 1 \mathrm{~mL})$. The crude oil was directly diluted with DCM and EtOH (DCM : EtOH $=10 \mathrm{~mL}: 1 \mathrm{~mL})$ and $\mathrm{NaBH}_{4}(10$ equiv.) was added. Upon complete consumption of the desired aldehyde, as indicated by TLC analysis, saturated $\mathrm{NH}_{4} \mathrm{Cl}(10 \mathrm{~mL})$ was added to the reaction mixture to quench the excess $\mathrm{NaBH}_{4}$. The mixture was then extracted with DCM (3 X $\left.20 \mathrm{~mL}\right)$. Combined organic layera were washed with $\mathrm{H}_{2} \mathrm{O}(20 \mathrm{~mL})$, brine $(20 \mathrm{~mL})$, dried over $\mathrm{MgSO}_{4}$ and concentrated in vacuo. Purification by flash silica gel column chromatography (silica gel, $25 \%$ ether in pentane) gave the title compound as clear oil ( $25.0 \mathrm{mg}, 84 \%$ yield, $90 \%$ ee). IR (film) 3362, 2910, 2853, 1448, 1027, $969 \mathrm{~cm}^{-1}$; ${ }^{1} \mathrm{H}$ NMR (400 MHz, $\left.\mathrm{CDCl}_{3}\right) \delta 5.51$ $(\mathrm{dd}, 1 \mathrm{H}, J=15.5,6.8 \mathrm{~Hz}, \mathrm{CH}=\mathrm{CH}), 5.09(\mathrm{ddd}, 1 \mathrm{H}, J=15.5,9.2,1.2 \mathrm{~Hz}, \mathrm{CH}=\mathrm{CH}), 3.53$ 
$\left(\mathrm{m}, 1 \mathrm{H}, \mathrm{HOCH}_{\mathrm{a}} \mathrm{H}_{\mathrm{b}}-\mathrm{CH}\right), 3.31\left(\mathrm{dt}, 1 \mathrm{H}, J=11.5,3.8 \mathrm{~Hz}, \mathrm{HOCH}_{\mathrm{a}} \mathbf{H}_{\mathrm{b}}-\mathrm{CH}\right), 2.12(\mathrm{~m}, 1 \mathrm{H}$, $\left.\mathrm{HOCH}_{\mathrm{a}} \mathrm{H}_{\mathbf{b}}-\mathrm{CH}\right), 1.95$ (m, 1H, CH=CH-CH-), 1.74-1.68 (m, 3H, HO-, -CH $\left.\mathbf{2}^{-}\right), 1.67-1.63$ $\left(\mathrm{m}, 1 \mathrm{H},-\mathbf{C H}_{2^{-}}\right), 1.42\left(\mathrm{dd}, 1 \mathrm{H}, J=8.4,2.4 \mathrm{~Hz},-\mathrm{CH}_{2^{-}}\right), 1.38-1.03\left(\mathrm{~m}, 16 \mathrm{H},-\mathrm{CH}_{2^{-}}\right), 0.89$ (t, $\left.3 \mathrm{H}, J=6.7 \mathrm{~Hz},-\mathrm{CH}_{3}\right), 0.88\left(\mathrm{t}, 3 \mathrm{H}, J=7.1 \mathrm{~Hz},-\mathrm{CH}_{3}\right) ;{ }^{13} \mathrm{C} \mathrm{NMR}\left(100 \mathrm{MHz}, \mathrm{CDCl}_{3}\right) \delta$ 140.5, 128.9, 66.2 , 46.2, 41.1, 33.6, 33.5, 32.1, 31.4, 29.6, 27.3, 26.3, 22.9, 14.4 ; HRMS (ESI-TOF) exact mass calculated for $[\mathrm{MH}]^{+\bullet}\left(\mathrm{C}_{16} \mathrm{H}_{31} \mathrm{O}\right)$ requires $\mathrm{m} / \mathrm{z}, 239.2369$, found $\mathrm{m} / \mathrm{z}$, 239.2370; $[\alpha]_{D}=-4.9\left(\mathrm{c}=0.65, \mathrm{CH}_{2} \mathrm{Cl}_{2}\right)$. The enantiomeric excess was determined by SFC analysis after conversion to 2-Naphtoyl derivative using a Chiralcel OJ-H column $\left(5 \% \mathrm{MeOH}\right.$, isocratic, $100 \mathrm{bar}, 35^{\circ} \mathrm{C}$ oven, flow $\left.=4.0 \mathrm{~mL} / \mathrm{min}\right) ;(R)$ isomer $\mathrm{t}_{\mathrm{r}}=4.54 \mathrm{~min}$, $(S)$ isomer $\mathrm{t}_{\mathrm{r}}=4.97 \mathrm{~min}$.

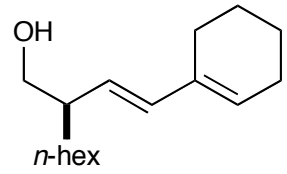

(R)-2-((1E)-2-cyclohexenylvinyl)octanol (Table 2, entry 10). Prepared according to the general procedure using acetone with 1-octanal and potassium trans-2cyclohexenylvinyl trifluoroborate. To a 2 dram vial equipped with a Teflon septum and a magnetic stir bar was added the $\mathrm{BF}_{3} \mathrm{~K}$ salt (134 mg, $0.625 \mathrm{mmol}, 5.0$ equiv.), (2S,5S)-5benzyl-2-tert-butyl-3-methylimidazolidin-4-one/ trifluoroacetic acid salt (9.0 mg, 0.025 mmol, $0.20 \mathrm{eq}$ ), CAN (171 mg, $0.312 \mathrm{mmol}, 2.5$ equiv.), and $\mathrm{NaHCO}_{3}$ (21 mg, 0.25 mmol, 2.0 equiv.). The vial was then cooled to $-78{ }^{\circ} \mathrm{C}$ before acetone $(2.0 \mathrm{~mL})$ and $\mathrm{H}_{2} \mathrm{O}$ (0.9 $\mathrm{mg}, 0.5 \mathrm{mmol}, 4$ equiv.) was added to the pre-cooled solid mixture. The reaction mixture was then carefully degassed through alternating vacuum evacuation and charging the vessel with argon ( $3 \mathrm{X})$. Aldehyde (16 mg, $0.125 \mathrm{mmol}, 1.0$ equiv.) was added after degassing of the reaction mixture and the reaction vial was moved and placed in $-50{ }^{\circ} \mathrm{C}$ cryocool. After $24 \mathrm{~h}$, the reaction was quenched cold with diethyl ether and stirred for 15 minutes during which precipitation of creamy white solid was observed. The reaction was then filtered through an iatrobeads plug and concentrated in vacuo $(\sim 1 \mathrm{~mL})$. The crude oil was directly diluted with DCM and EtOH (DCM : EtOH $=10 \mathrm{~mL}: 1 \mathrm{~mL})$ and $\mathrm{NaBH}_{4}$ 
(10 equiv.) was added. Upon complete consumption of the desired aldehyde, as indicated by TLC analysis, saturated $\mathrm{NH}_{4} \mathrm{Cl}(10 \mathrm{~mL})$ was added to the reaction mixture to quench the excess $\mathrm{NaBH}_{4}$. The mixture was then extracted with DCM (3 X $\left.20 \mathrm{~mL}\right)$. Combined organic layers were washed with $\mathrm{H}_{2} \mathrm{O}(20 \mathrm{~mL})$, brine $(20 \mathrm{~mL})$, dried over $\mathrm{MgSO}_{4}$ and concentrated in vacuo. Purification by flash silica gel column chromatography (silica gel, $25 \%$ ether in pentane) gave the title compound as clear oil (21.6 mg, $73 \%$ yield, 93\% ee). IR (film) 3362, 2910, 2853, 1448, 1027, 969 $\mathrm{cm}^{-1}$; ${ }^{1} \mathrm{H}$ NMR (400 MHz, CDCl ${ }_{3}$ ) 6.13 (d, $1 \mathrm{H}, J=15.5 \mathrm{~Hz}, \mathrm{CH}=\mathrm{CH}), 5.71(\mathrm{~s}, 1 \mathrm{H}, \mathrm{CH}=\mathrm{CH}), 5.26(\mathrm{dd}, 1 \mathrm{H}, J=15.5,8.8 \mathrm{~Hz}$, $\mathrm{CH}=\mathrm{CH}), 3.57\left(\mathrm{ddd}, 1 \mathrm{H}, J=10.4,8.8,5.2 \mathrm{~Hz}, \mathrm{HOCH}_{\mathrm{a}} \mathrm{H}_{\mathrm{b}}-\mathrm{CH}\right), 3.38(\mathrm{ddd}, 1 \mathrm{H}, J=10.4$, 8.4, 3.6 Hz, $\left.\mathrm{HOCH}_{\mathrm{a}} \mathbf{H}_{\mathrm{b}}-\mathrm{CH}\right), 2.12\left(\mathrm{~m}, 1 \mathrm{H}, \mathrm{HOCH}_{\mathrm{a}} \mathrm{H}_{\mathrm{b}}-\mathrm{CH}\right), 2.18\left(\mathrm{~m}, 3 \mathrm{H}, \mathrm{CH}=\mathrm{CH}-\mathrm{CH}_{2}-\right)$, 1.71-1.63 (m, 2H, CH=CH-CH-), 1.61-1.60 (m, 2H, $\left.-\mathrm{CH}_{2}-\right), 1.43-1.36\left(\mathrm{~m}, 2 \mathrm{H},-\mathbf{C H}_{2^{-}}\right)$, 1.31-1.20 (m, 10H, $\left.-\mathrm{CH}_{2}-\right), 0.88\left(\mathrm{t}, 3 \mathrm{H}, J=6.4 \mathrm{~Hz},-\mathrm{CH}_{3}\right) ;{ }^{13} \mathrm{C} \mathrm{NMR}\left(100 \mathrm{MHz}, \mathrm{CDCl}_{3}\right)$ $\delta 136.3,135.2,128.6,127.1,66.2,46.2,31.7,31.4,29.4,27.1,25.8,24.6,22.6,22.5$, 22.4, 14.1 ; HRMS (ESI-TOF) exact mass calculated for $[\mathrm{MH}]^{+\bullet}\left(\mathrm{C}_{16} \mathrm{H}_{29} \mathrm{O}\right)$ requires $\mathrm{m} / \mathrm{z}$ 237.2213, found $\mathrm{m} / z$ 237.2206; $[\alpha]_{\mathrm{D}}=-3.4\left(\mathrm{c}=0.65, \mathrm{CH}_{2} \mathrm{Cl}_{2}\right)$. The enantiomeric excess was determined by SFC analysis using a Chiralcel AD-H column $(15 \% \mathrm{EtOH}$, isocratic, $100 \mathrm{bar}, 35^{\circ} \mathrm{C}$ oven, flow $\left.=3.0 \mathrm{~mL} / \mathrm{min}\right) ;(S)$ isomer $\mathrm{t}_{\mathrm{r}}=3.51 \mathrm{~min},(R)$ isomer $\mathrm{t}_{\mathrm{r}}=3.78$ $\min$.

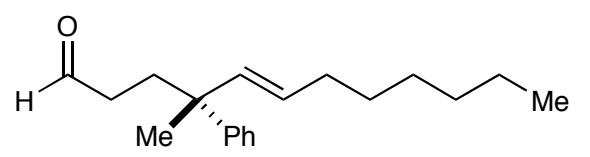

(R)-4-methyl-4-phenyl-(5E)dodecenal (Scheme 1). Vinylation was done according to the general procedure using DME with 1-octanal and potassium trans- $\alpha$ methyl styryl trifluoroborate. To a 2 dram vial equipped with a Teflon septum and a magnetic stir bar was added the $\mathrm{BF}_{3} \mathrm{~K}$ salt (140 mg, $0.75 \mathrm{mmol}, 3.0$ equiv.), (2S,5S)-5benzyl-2-tert-butyl-3-methylimidazolidin-4-one ( $18 \mathrm{mg}, 0.05 \mathrm{mmol}, 0.20 \mathrm{eq}$ ), CAN (342 $\mathrm{mg}, 0.625 \mathrm{mmol}, 2.5$ equiv.), and $\mathrm{NaHCO}_{3}(42 \mathrm{mg}, 0.5 \mathrm{mmol}, 2.0$ equiv.). The vial was then cooled to $-78{ }^{\circ} \mathrm{C}$ before DME $(1.0 \mathrm{~mL})$ and $\mathrm{H}_{2} \mathrm{O}(1.8 \mathrm{mg}, 1.0 \mathrm{mmol}, 4$ equiv.) was 
added to the pre-cooled solid mixture. The reaction mixture was then carefully degassed through alternating vacuum evacuation and charging the vessel with argon (3X). Aldehyde (32 mg, $0.25 \mathrm{mmol}, 1.0$ equiv.) was added after degassing of the reaction mixture and the reaction vial was moved and placed in $-50{ }^{\circ} \mathrm{C}$ cryocool. After $24 \mathrm{~h}$, the reaction was quenched cold with diethyl ether and stirred for 15 minutes during which precipitation of creamy white solid was observed. The reaction was then filtered through an iatrobeads plug and concentrated in vacuo $(\sim 1 \mathrm{~mL})$. THF $(1.0 \mathrm{ml})$ was added to this crude mixture and concentrated again in vacuo $(\sim 1 \mathrm{~mL})$. This was repeated 3 times after which the solvent exchanged crude mixture was directly transferred to a flame dried 10 $\mathrm{ml}$ round bottom flask equipped with a stir bar. The flask was then cooled to $-78{ }^{\circ} \mathrm{C}$ before vinyl magnesium chloride reagent (1.6 M in THF, $1.0 \mathrm{~mL}, 1.6 \mathrm{mmol}, 6.4$ equiv.) was added dropwise to the crude mixture. The cooling bath was removed and the reaction was warmed to room temperature. After TLC indicated the disappearance of the aldehyde $(\sim 8 \mathrm{~h})$, the reaction was quenched with $1 \mathrm{~N} \mathrm{HCl}$. The mixture was then extracted with Ether (3 X $20 \mathrm{~mL})$. Combined organic layer was washed with $\mathrm{H}_{2} \mathrm{O}(20 \mathrm{~mL})$, Brine (20 $\mathrm{mL}$ ), dried under $\mathrm{MgSO}_{4}$ and concentrated in vacuo. Purification by flash silica gel column chromatography (silica gel, 25\% ether in pentane) gave the desired allylic alcohol as clear oil (52.0 mg, 76\% yield) which was carried on directly to the anionic oxy-Cope rearrangement without further purification. To a flame-dried $10 \mathrm{~mL}$ round bottom flask equipped with a stir bar was added sequentially THF $(1.0 \mathrm{~mL})$ and $\mathrm{KH}(10 \mathrm{mg})$ under positive pressure of argon and cooled to $0{ }^{\circ} \mathrm{C}$. In a separate vial, previously obtained allylic alcohol $(52.0 \mathrm{mg})$ and $18-\mathrm{C}-6(50.1 \mathrm{mg}, 0.19 \mathrm{mmol}, 1.0$ equiv.) was dissolved in THF $(1.0 \mathrm{~mL})$. This mixture was then added dropwise via syringe to the flask containing THF solution of KH over 1 min. Upon addition of the alcohol/18-C- 6 solution, the reaction turned from clear to tan within $1 \mathrm{~h}$. Color of the reaction changed as the reaction progressed until it turned dark brown $(\sim 24 \mathrm{~h})$ at which point the TLC indicated full conversion of the allylic alcohol. The reaction mixture was cooled to $-78{ }^{\circ} \mathrm{C}$ and $\mathrm{MeOH}$ $(1.0 \mathrm{~mL})$ was added dropwise over $2 \mathrm{~min}$ to quench the reaction. After stirring for 30 $\mathrm{min}$, the reaction was diluted with ether $(40 \mathrm{~mL})$, washed with $\mathrm{H}_{2} \mathrm{O}(20 \mathrm{~mL})$, Brine (20 
$\mathrm{mL}$ ), dried under $\mathrm{MgSO}_{4}$ and concentrated in vacuo. Purification by flash silica gel column chromatography (silica gel, 5\% ether in pentane) gave the desired aldehyde as clear oil (40.1 mg, 80\% yield, 94\% ee). IR (film) 2953, 2917, 285, 1726, 1494, 1445, 1377, 1030, 976, 763, $699 \mathrm{~cm}^{-1} ;{ }^{1} \mathrm{H}$ NMR (400 MHz, $\mathrm{CDCl}_{3}$ ) $\delta 9.70$ (t, $1 \mathrm{H}, J=1.3 \mathrm{~Hz}$, OHC-), 7.32-7.31 (m, 4H, aryl-H), 7.22-7.19 (m, 1H, aryl-H), 5.59 (dt, $1 \mathrm{H}, J=15.5,1.2$ $\mathrm{Hz}, \mathrm{CH}=\mathrm{CH}), 5.09(\mathrm{dt}, 1 \mathrm{H}, J=15.5,6.5 \mathrm{~Hz}, \mathrm{CH}=\mathrm{CH}), 2.36-2.26\left(\mathrm{~m}, 2 \mathrm{H}, \mathrm{OHC}-\mathrm{CH}_{\mathrm{a}} \mathbf{H}_{\mathbf{b}}-\right.$ $\mathrm{CH}$ ), 2.16-2.10 (m, 2H, CH=CH-CH-), 1.44-1.26 (m, 10H, - $\left.\mathrm{CH}_{2}-\right), 1.36\left(\mathrm{~s}, 3 \mathrm{H},-\mathrm{CH}_{3}\right)$, 0.90 (t, 3H, $\left.J=6.8 \mathrm{~Hz},-\mathrm{CH}_{3}\right) ;{ }^{13} \mathrm{C} \mathrm{NMR}\left(100 \mathrm{MHz}, \mathrm{CDCl}_{3}\right) \delta$ 202.7, 137.6, 128.7, 128.3, 127.2, 126.6, 126.0, 42.8, 40.1, 33.0, 32.8, 31.7, 29.6, 28.9, 25.8, 22.7, 14.2 ; HRMS (ESI-TOF) exact mass calculated for $[\mathrm{MH}]^{+\bullet}\left(\mathrm{C}_{19} \mathrm{H}_{29} \mathrm{O}\right)$ requires $\mathrm{m} / \mathrm{z} 273.2213$, found $\mathrm{m} / \mathrm{z}$ 273.2205; $[\alpha]_{D}=-0.16\left(\mathrm{c}=0.16, \mathrm{CH}_{2} \mathrm{Cl}_{2}\right)$. The enantiomeric excess was determined by SFC analysis after conversion to the corresponding alcohol via $\mathrm{NaBH}_{4}$ reduction using a Chiralcel AS-H column $\left(5-10 \% \mathrm{MeOH}\right.$, linear gradient, 38 bar, $35{ }^{\circ} \mathrm{C}$ oven, flow $=4.0$ $\mathrm{mL} / \mathrm{min}) ;(S)$ isomer $\mathrm{t}_{\mathrm{r}}=1.63 \min ,(R)$ isomer $\mathrm{t}_{\mathrm{r}}=1.80 \mathrm{~min}$. 